Article

\title{
Unifying Molecular Weights of Highly Linear Polyethylene Waxes through Unsymmetrical 2,4-Bis(imino)pyridylchromium Chlorides
}

\author{
Badral Gansukh ${ }^{1,2,+}$, Qiuyue Zhang ${ }^{1,2,+}+\mathbb{D}$, Chantsalnyam Bariashir ${ }^{1}$, Arumugam Vignesh ${ }^{1}$, \\ Yanping Ma ${ }^{1, *(\mathbb{D})}$, Tongling Liang ${ }^{1}$ and Wen-Hua Sun ${ }^{1,2,3, *(\mathbb{D})}$ \\ 1 Key Laboratory of Engineering Plastics and Beijing National Laboratory for Molecular Sciences, \\ Institute of Chemistry, Chinese Academy of Sciences, Beijing 100190, China; baagii11a@iccas.ac.cn (B.G.); \\ zhangqiuyue@iccas.ac.cn (Q.Z.); bariashir@iccas.ac.cn (C.B.); avignesh@iccas.ac.cn (A.V.); \\ 1t1@iccas.ac.cn (T.L.) \\ 2 CAS Research/Education Center for Excellence in Molecular Sciences, University of Chinese Academy \\ of Sciences, Beijing 100049, China \\ 3 State Key Laboratory for Oxo Synthesis and Selective Oxidation, Lanzhou Institute of Chemical Physics, \\ Chinese Academy of Sciences, Lanzhou 730000, China \\ * Correspondence: myanping@iccas.ac.cn (Y.M.); whsun@iccas.ac.cn (W.-H.S.); \\ Tel.: +86-10-6255-7955 (W.-H.S.) \\ + These authors contributed equally to this work.
}

Academic Editor: Evgueni Kirillov

Received: 9 November 2020; Accepted: 24 November 2020; Published: 27 November 2020

check for updates

\begin{abstract}
By dealing $\mathrm{CrCl}_{3} \cdot 3 \mathrm{THF}$ with the corresponding ligands (L1-L5), an array of fluoro-substituted chromium (III) chlorides (Cr1-Cr5) bearing 2-[1-(2,4-dibenzhydryl-6-fluorophenylimino)ethyl]-6-[1-(arylimino)ethyl]pyridine (aryl = 2,6- $\mathrm{Me}_{2} \mathrm{Ph} \mathrm{Cr} 1,2,6-\mathrm{Et}_{2} \mathrm{Ph} \mathrm{Cr}$, 2,6-iPr $2 \mathrm{Ph}$ $\left.\mathrm{Cr} 3,2,4,6-\mathrm{Me}_{3} \mathrm{Ph} \mathrm{Cr} 4,2,6-\mathrm{Et}_{2}-4-\mathrm{MePh} \mathrm{Cr} 5\right)$ was synthesized in good yield and validated via Fourier Transform Infrared (FT-IR) spectroscopy and elemental analysis. Besides the routine characterizations, the single-crystal X-ray diffraction study revealed the solid-state structures of complexes $\mathbf{C r} 2$ and $\mathbf{C r} 4$ as the distorted-octahedral geometry around the chromium center. Activated by either methylaluminoxane (MAO) or modified methylaluminoxane (MMAO), all the chromium catalysts exhibited high activities toward ethylene polymerization with the MMAO-promoted

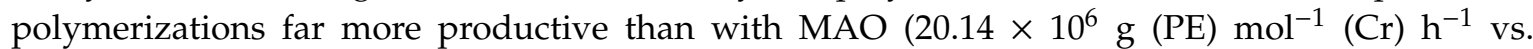
$\left.10.03 \times 10^{6} \mathrm{~g}(\mathrm{PE}) \mathrm{mol}^{-1}(\mathrm{Cr}) \mathrm{h}^{-1}\right)$. In both cases, the resultant polyethylenes were found as highly linear polyethylene waxes with low molecular weights around $1-2 \mathrm{~kg} \mathrm{~mol}^{-1}$ and narrow molecular weight distribution (MWD range: 1.68-2.25). In general, both the catalytic performance of the ortho-fluorinated chromium complexes and polymer properties have been the subject of a detailed investigation and proved to be highly dependent on the polymerization reaction parameters (including cocatalyst type and amount, reaction temperature, ethylene pressure and run time).
\end{abstract}

Keywords: ortho-fluorinated chromium pre-catalysts; ethylene polymerization; highly linear PE waxes; single-site catalysis

\section{Introduction}

Since silica-supported Phillips [1-5] and Union Carbide [6-8] catalyst systems became extensively used in commercial production of polyolefins, the development of Cr-based catalysts has been a critical research issue for researchers [9-31]. Many efforts have been made to expanded the type of heterogeneous and homogeneous catalysts based on chromium for 
ethylene oligomerization, polymerization [13-25] as well as for ethylene trimerization [26-30] and tetramerization [31]. As homogeneous catalysts allow the production of polymers with narrow molecular weight distributions compared to heterogeneous ones [32-37], the exploration of promising homogeneous chromium precatalysts for ethylene oligomerization and/or polymerization by exploiting new ancillary ligands framework has gradually become one of the hot issues of research in this field $[3,14,19,21,23,38]$. Subsequently, on the basis of the classical model of 2,6-bis(imino)pyriylchromium (III) precatalysts (A, Chart 1) [23,39-41], numerous structural modifications have been made to improve the 2,6-diiminopyridine framework including 2-quinoxalinyl-6-iminopyridines (B, Chart 1) [42], 2-benzimidazolyl-6-(1-(arylimino)ethyl)pyridines (C, Chart 1) [43,44] and cycloalkyl-fused bis(arylimino)pyridines (D, Chart 1) [45-48] as well as their derivatives [49-53]. The chromium complexes $\mathbf{B}$ and $\mathbf{C}$ (Chart 1) and their derivatives showed moderate or high activities towards ethylene oligo-/polymerization generating oligomers or a mixture of oligomers and polyethylene waxes [42-44,49-51], while all the cycloalkyl-fused bis(arylimino)pyridylchromium (III) complexes (D, Chart 1) were able to produce strictly linear polyethylenes or vinyl-terminated polyethylene waxes [52]. In addition, functionalizing ortho-position of $\mathrm{N}$-aryl groups with bulky dibenzhydryl substituents can increase the steric demand of the whole ligand set and shield the apical positions of the coordination-planar metal centers [54-61]. Consequently, 2-(1-(2,6-dibenzhydryl-4- $R$-phenyl imino)-ethyl)-6-(1-(arylimino)ethyl)pyridylchromium (III) precatalysts ( $\mathrm{R}=\mathrm{NO}_{2}, t$-butyl) (E, Chart 1$)$ were reported to exhibit moderate activities toward ethylene polymerization while produce high-molecular-weight linear polyethylenes [62,63]; thereinto, nitro-enhanced 2,6-bis(imino)pyridylchromium (III) chlorides had a definite advantage in increasing catalytic activity and molecular weight over $t$-butyl-functionalized 2,6-bis(imino)pyridylchromium (III) chlorides.

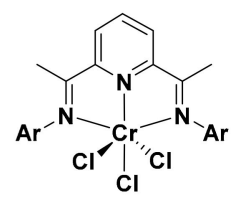

A

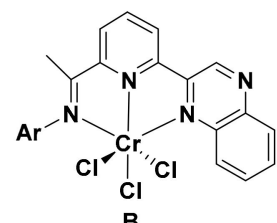

B

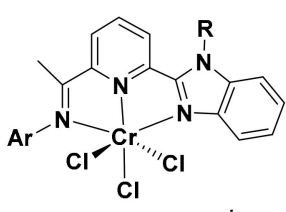

C $\left(\mathrm{R}=\mathrm{H},{ }^{i} \mathrm{Pr}\right)$

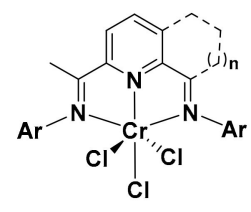

$D(n=0,1,2)$

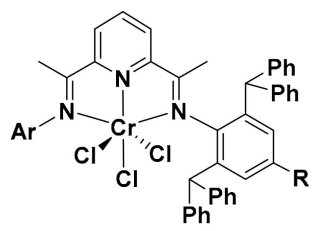

$\mathrm{E}\left(\mathrm{R}=\mathrm{NO}_{2},{ }^{t}\right.$ butyl $)$

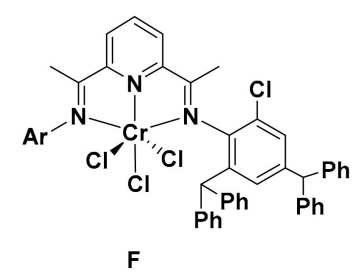

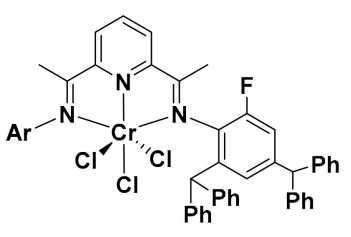

G (Current Work)

Chart 1. Chromium (III) pre-catalysts (B-G) derived from 2,6-bis(arylimino)pyridine-containing (A).

Inspired by the positive result brought by the nitro electron-withdrawing group, the halogen atom has been introduced to the ortho-position of $N$-aryl groups $(\mathbf{F}$, Chart 1$)$ to enhance their catalytic performance of bis(imino)pyridyl chromium catalysts. Surprisingly, the ortho-chloro-substituted 2-[1-(2,4-dibenzhydryl-6-chlorophenylimino)ethyl]-6-[1-(arylimino)ethyl]- pyridylchromium (III) chloride precatalysts [64] were found to display high activity (up to $14.96 \times 10^{6} \mathrm{~g}(\mathrm{PE}) \mathrm{mol}^{-1}(\mathrm{Cr}) \mathrm{h}^{-1}$ at $60{ }^{\circ} \mathrm{C}$ ) affording highly linear polyethylene with moderate molecular weight $\left(\mathrm{M}_{\mathrm{W}}\right)$ ranging from 4.01 to $22.06 \mathrm{~kg} \mathrm{~mol}^{-1}$. With a view to further explore the effect of ortho-fluoro group with stronger electron-withdrawing ability on catalytic performance of chromium catalysts, herein, we report the synthesis route and characterization data of the ortho-fluoro substituted 2,4-bis(imino)pyridylchromium (III) chloride complexes (G, Chart 1) along with their ethylene polymerization behavior. A detailed catalytic evaluation of these chromium catalysts was performed using methylaluminoxane (MAO) and modified methylaluminoxane (MMAO) as cocatalysts to identify the most suitable polymerization 
conditions. Moreover, the correlation between the properties of resultant polymers and the electronic and steric effect of the ligand framework as well as the reaction parameters will be discussed at length.

\section{Results}

\subsection{Synthesis and Characterization}

The diiminopyridine derivatives (L1-L5) were prepared in moderate yields by a two-step procedure (Scheme 1) [62-64] and confirmed by various characterization methods including ${ }^{1} \mathrm{H} /{ }^{13} \mathrm{C}$ Nuclear Magnetic Resonance (NMR), FT-IR spectra and elemental analysis [49,55,57]. The stoichiometric reactions of the diiminopyridine compounds (L1-L5) with $\mathrm{CrCl}_{3} \cdot 3 \mathrm{THF}$ in dichloromethane being stirred for $10 \mathrm{~h}$ under room temperature gave corresponding 2-[1-(2,4dibenzhydryl-6-fluorophenyl-imino)ethyl]-6-[1-(arylimino)ethyl]pyridylchromium (III) chlorides [aryl $=2,6-\mathrm{Me}_{2} \mathrm{C}_{6} \mathrm{H}_{3}$ (Cr1), 2,6- $\mathrm{Et}_{2} \mathrm{C}_{6} \mathrm{H}_{3}$ (Cr2), 2,6- ${ }^{i} \mathrm{Pr}_{2} \mathrm{C}_{6} \mathrm{H}_{3}$ (Cr3), 2,4,6- $\mathrm{Me}_{3} \mathrm{C}_{6} \mathrm{H}_{2}$ (Cr4), 2,6-Et ${ }_{2}-4-\mathrm{MeC}_{6} \mathrm{H}_{2}$ (Cr5) in good yields (80-87\%). The FTIR spectra of these chromium complexes show that the $v(C=N)_{\text {imine }}$ stretching frequencies fell in the range $1611-1618 \mathrm{~cm}^{-1}$ which compared to $1638-1643$ $\mathrm{cm}^{-1}$ for the free ligands indicating an effective coordination between the imine-nitrogen and the chromium metal. The coordination of chromium with nitrogen atom in ortho-chloro substituted chromium (III) complexes can cause less redshifts (around $21 \mathrm{~cm}^{-1}$ ) of the $\mathrm{C}=\mathrm{N}$ absorption band than that (around $26 \mathrm{~cm}^{-1}$ ) in ortho-floro substituted chromium (III) complexes a result of different donor structure [64]. Moreover, the molecular structures of Cr2 and Cr4 were further confirmed by the single-crystal X-ray diffraction.

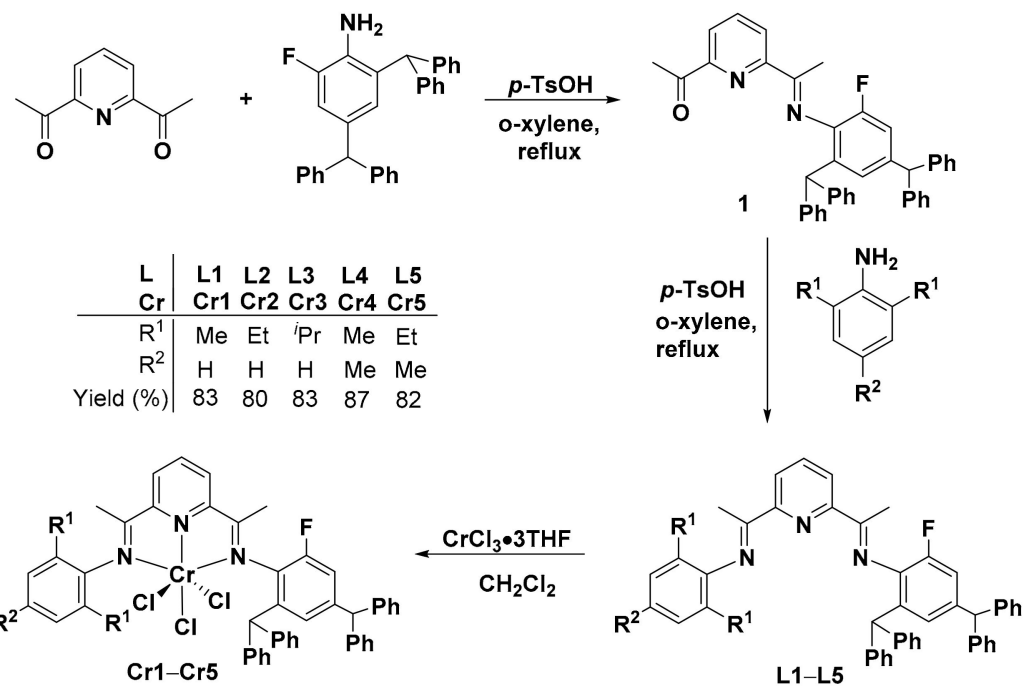

Scheme 1. Synthesis of ligands L1-L5 and the corresponding chromium complexes (Cr1-Cr5).

\subsection{X-ray Crystallographic Studies}

Single-crystals of the complexes $\mathbf{C r} 2$ and $\mathbf{C r} 4$ suitable for the X-ray determination were individually grown by the slow diffusion of $n$-heptane into their respective dichloromethane solutions. The Oak Ridge Thermal Ellipsoid Plot (ORTEP) diagrams of Cr2 and Cr4 are presented in Figure 1, respectively while the selected bond lengths and angles of $\mathbf{C r} 2$ and $\mathbf{C r} 4$ are listed in Table 1. These two complexes have similar coordination geometry hence they will be discussed together. Complexes $\mathbf{C r} 2$ and $\mathbf{C r} 4$ were mononuclear species in which chromium center coordinated with three chloride atoms forming a six-coordinate geometry described as a distorted-octahedral geometry. These three chloride ligands were disposed in a mer arrangement. The C11, N1, N2, and N3 atoms constituted the equatorial plane while two axial bonds nearly formed a linear through the chromium center $\left[\mathrm{Cl}(1)-\mathrm{Cr}(1)-\mathrm{Cl}(3), 91.04(8)^{\circ}\right.$ for $\mathrm{Cr} 2$ and $93.74(4)^{\circ}$ for $\mathrm{Cr} 4$, respectively]. The bond length of $\mathrm{Cr}_{-} \mathrm{N}_{\text {pyridine }}(\mathrm{Cr} 1-\mathrm{N} 1,2.003(5) \AA$ for $\mathrm{Cr} 2$ 
and 1.985(3) $\AA$ for $\mathrm{Cr} 4$ ) was evidently shorter than that of corresponding $\mathrm{Cr}-\mathrm{N}_{\text {imino }}$ (Cr1-N2, 2.157(5) $\AA$ and $\mathrm{Cr} 1-\mathrm{N} 3,2.133(5) \AA$ for $\mathrm{Cr} 2$; Cr1-N2, 2.132(3) $\AA$ and $\mathrm{Cr} 1-\mathrm{N} 3,2.136(3) \AA$ for Cr4) highlighting that a stronger bond between the pyridine donor and the metal center was present than that between the imine-nitrogen and the metal center. Compared to the ortho-chloro substituted chromium (III) complexes, in this work the $\mathrm{Cr}-\mathrm{N}_{\text {pyridine }}$ bond length was longer [2.003(5) $\AA$ vs. 1.994(2) $\AA$ for $\mathrm{Cr} 2$ in both cases] while $\mathrm{Cr}-\mathrm{Cl}$ and imine bond lengths were generally shorter due to the halogen effects [64]. Furthermore, the obvious deviation of bond lengths of the two $\mathrm{Cr}_{-} \mathrm{N}_{\mathrm{imino}}$ bonds (Cr1-N2 and Cr1-N3) in $\mathrm{Cr} 2$ and $\mathrm{Cr} 4$ was mainly due to the unsymmetrical framework consistent with the observations of their analogs [49-53,62-64]. The bond lengths of the two imine nitrogen atoms in Cr4 were also distinct (1.297(5) for C2-N2 and 1.2817(6) for C8-N3), potentially due to different steric properties of $N$-aryl groups [62,63].

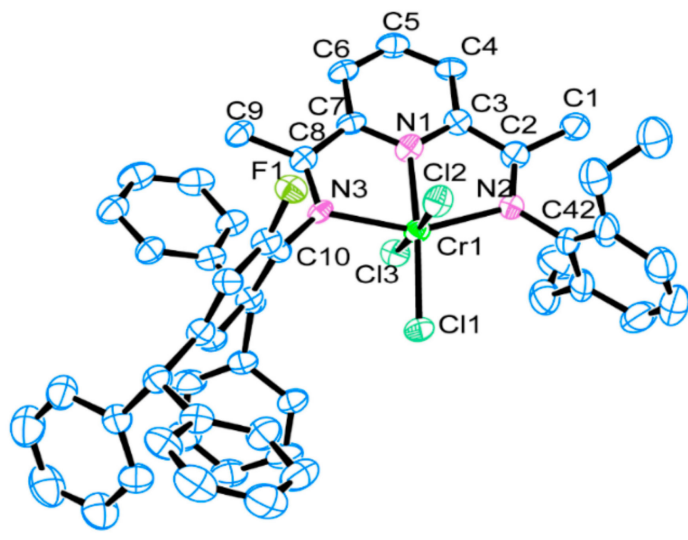

(a)

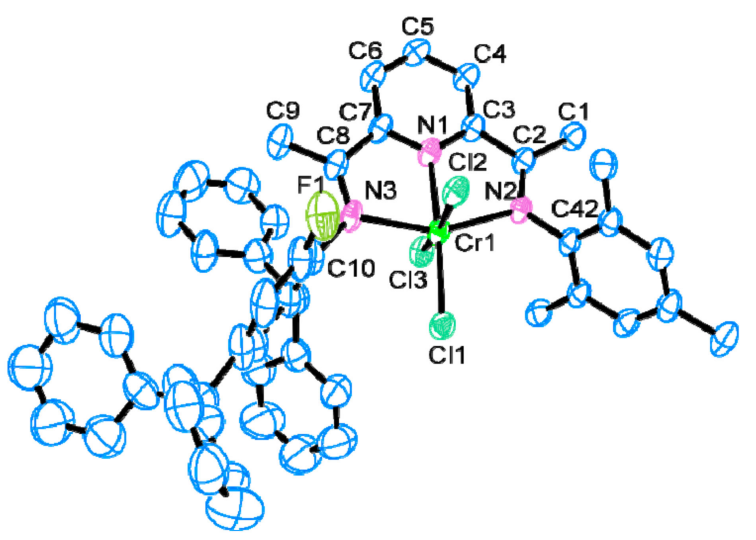

(b)

Figure 1. ORTEP drawing of Cr2 (a) and Cr4 (b) with thermal ellipsoids set at a $30 \%$ probability level. For clarity purposes, all $\mathrm{H}$ atoms are omitted in both cases.

Table 1. Selected bond lengths and angles for Cr2 and Cr4.

\begin{tabular}{|c|c|c|c|c|c|}
\hline & Cr2 & $\mathrm{Cr} 4$ & & Cr2 & $\mathrm{Cr} 4$ \\
\hline \multicolumn{3}{|c|}{ bond lengths $(\AA)$} & \multicolumn{3}{|c|}{ bond angles $\left(^{\circ}\right)$} \\
\hline $\mathrm{Cr} 1-\mathrm{Cl1}$ & $2.2900(18)$ & $2.2757(12)$ & Cl1-Cr1-N1 & $174.81(17)$ & $176.21(10)$ \\
\hline $\mathrm{Cr} 1-\mathrm{Cl} 2$ & $2.2788(19)$ & $2.3295(12)$ & Cl1-Cr1-N2 & $107.04(15)$ & $105.71(9)$ \\
\hline $\mathrm{Cr} 1-\mathrm{Cl} 3$ & $2.3217(19)$ & $2.3278(12)$ & $\mathrm{Cl1}-\mathrm{Cr} 1-\mathrm{N} 3$ & $99.53(14)$ & $99.22(11)$ \\
\hline Cr1-N1 & $2.003(5)$ & $1.985(3)$ & $\mathrm{Cl} 2-\mathrm{Cr} 1-\mathrm{N} 1$ & $91.48(15)$ & $82.50(10)$ \\
\hline Cr1-N2 & $2.157(5)$ & $2.132(3)$ & $\mathrm{Cl} 2-\mathrm{Cr} 1-\mathrm{N} 2$ & 89.18 (15) & $88.62(9)$ \\
\hline Cr1-N3 & $2.133(5)$ & $2.136(3)$ & $\mathrm{Cl} 2-\mathrm{Cr} 1-\mathrm{N} 3$ & $86.33(14)$ & $89.58(10)$ \\
\hline $\mathrm{C} 2-\mathrm{N} 2$ & $1.290(8)$ & $1.297(5)$ & $\mathrm{Cl3}-\mathrm{Cr} 1-\mathrm{N} 1$ & 85.08 (15) & $87.23(10)$ \\
\hline $\mathrm{C} 8-\mathrm{N} 3$ & $1.299(7)$ & $1.281(6)$ & $\mathrm{Cl} 3-\mathrm{Cr} 1-\mathrm{N} 2$ & $91.29(15)$ & $88.38(9)$ \\
\hline \multicolumn{3}{|c|}{ bond angles $\left({ }^{\circ}\right)$} & $\mathrm{Cl} 3-\mathrm{Cr} 1-\mathrm{N} 3$ & $91.61(14)$ & $88.98(10)$ \\
\hline $\mathrm{Cl} 1-\mathrm{Cr} 1-\mathrm{Cl} 2$ & $92.31(8)$ & $96.57(5)$ & $\mathrm{N} 1-\mathrm{Cr} 1-\mathrm{N} 2$ & $76.5(2)$ & $77.97(13)$ \\
\hline $\mathrm{Cl1}-\mathrm{Cr} 1-\mathrm{Cl} 3$ & $91.04(8)$ & $93.74(4)$ & N1-Cr1-N3 & $77.2(2)$ & $77.12(14)$ \\
\hline $\mathrm{Cl} 2-\mathrm{Cr} 1-\mathrm{Cl} 3$ & $176.31(8)$ & $169.69(5)$ & N2-Cr1-N3 & $153.20(19)$ & $155.05(14)$ \\
\hline
\end{tabular}

\subsection{Ethylene Polymerization}

To identify a suitable polymerization condition that can be used to evaluate all the five chromium pre-catalysts (Cr1-Cr5) for the polymerization of ethylene, $\mathbf{C r} 4$ was chosen as the test precatalyst in the first instance to allow an optimization of various catalytic parameters. Based on previous studies of structurally related $N, N, N$-bound chromium(III) complexes [49-53,64], methylaluminoxane (MAO) and modified methylaluminoxane (MMAO) have proved the most effective co-catalysts to promote ethylene polymerization. Hence, these two cocatalysts were employed to activate the chromium precatalysts and the optimum reaction conditions including run temperature, $\mathrm{Al} / \mathrm{Cr}$ molar ratio, reaction time and 
ethylene pressure were separately ascertained for the catalytic system composed of $\mathrm{Cr} 4 / \mathrm{MAO}$ and Cr4/MMAO.

\subsubsection{Catalytic Evaluation of Cr4/MAO Catalytic System}

With the reaction temperature fixed at $30{ }^{\circ} \mathrm{C}$, variation of the molar ratio $\mathrm{Al} / \mathrm{Cr}$ from 2000 to 4000 was investigated (entries 1-7, Table 2). As the Al/Cr molar ratio was increased, the catalytic activity reached a maximum of $\left.5.46 \times 10^{6} \mathrm{~g} \mathrm{PE}\right) \mathrm{mol}^{-1}(\mathrm{Cr}) \mathrm{h}^{-1}$ at the $\mathrm{Al} / \mathrm{Cr}$ ratio of 3500 (entry 5 , Table 2). The Gel Permeation Chromatography (GPC) data generally revealed a narrow and unimodal polydispersity $\left(\mathrm{M}_{\mathrm{w}} / \mathrm{M}_{\mathrm{n}}\right.$ range = 1.46-1.89) for the polyethylene formed (Figure 2a); moreover, there was no clear effects shown by the amount of co-catalyst on the molecular weight with very similar values observed across the ratio range $\left(M_{w}=1.04-1.22 \mathrm{~kg} \mathrm{~mol}^{-1}\right)$. Interestingly, the Melting temperature $\left(\mathrm{T}_{\mathrm{m}}\right)$ value of the resultant polymers followed a similar trend with their corresponding molecular weights (Table 2), a finding that indicates the highly linear properties of the obtained polymers [64].

On varying the polymerization temperature from 30 to $70{ }^{\circ} \mathrm{C}$ with the $\mathrm{Al} / \mathrm{Cr}$ molar ratio fixed at 3500 and the reaction time for $30 \mathrm{~min}$ (entries 5, 8-11, Table 2), a peak in catalytic activity was achieved of $10.03 \times 10^{6} \mathrm{~g}(\mathrm{PE}) \mathrm{mol}^{-1}(\mathrm{Cr}) \mathrm{h}^{-1}$ at $60^{\circ} \mathrm{C}$. Further raising the temperature to $70{ }^{\circ} \mathrm{C}$ led to a rapid decrease in its activity from $10.03 \times 10^{6} \mathrm{~g}(\mathrm{PE}) \mathrm{mol}^{-1}(\mathrm{Cr}) \mathrm{h}^{-1}$ to $6.24 \times 10^{6} \mathrm{~g}(\mathrm{PE}) \mathrm{mol}^{-1}(\mathrm{Cr}) \mathrm{h}^{-1}$ (Figure 2b), which can be ascribed to the partial deactivation of the active species resulting from increased chain transfer to aluminum at the higher temperature [65-69] and the lower solubility of ethylene in toluene at elevated temperatures [70-72]. Although the molecular weights obtained at different temperatures have little difference, the highest molecular weight $\left(1.61 \mathrm{~kg} \mathrm{~mol}^{-1}\right)$ obtained at the optimum temperature $60{ }^{\circ} \mathrm{C}$ somehow reflects more probability of chain propagation at this temperature [57].

Table 2. Ethylene polymerization studies with $\mathrm{Cr} 4 / \mathrm{MAO}^{\mathrm{a}}$.

\begin{tabular}{|c|c|c|c|c|c|c|c|c|c|}
\hline Entry & Cat. & $\mathrm{Al}: \mathrm{Cr}$ & $T,{ }^{\circ} \mathrm{C}$ & $t, \min$ & PE, $g$ & Activity ${ }^{b}$ & $M_{\mathrm{w}}^{\mathrm{c}}$ & $M_{\mathrm{w}} / M_{\mathrm{n}}^{\mathrm{c}}$ & $T_{m}{ }^{d},{ }^{\circ} \mathrm{C}$ \\
\hline 1 & $\mathrm{Cr} 4$ & 2000 & 30 & 30 & 1.08 & 1.08 & 1.05 & 1.68 & 120.6 \\
\hline 2 & $\mathrm{Cr} 4$ & 2500 & 30 & 30 & 1.97 & 1.97 & 1.11 & 1.71 & 121.1 \\
\hline 3 & $\mathrm{Cr} 4$ & 3000 & 30 & 30 & 3.27 & 3.27 & 1.15 & 1.46 & 122.0 \\
\hline 4 & $\mathrm{Cr} 4$ & 3250 & 30 & 30 & 5.14 & 5.14 & 1.17 & 1.79 & 122.8 \\
\hline 5 & $\mathrm{Cr} 4$ & 3500 & 30 & 30 & 5.46 & 5.46 & 1.22 & 1.89 & 122.9 \\
\hline 6 & $\mathrm{Cr} 4$ & 3750 & 30 & 30 & 4.78 & 4.78 & 1.09 & 1.69 & 122.7 \\
\hline 7 & $\mathrm{Cr} 4$ & 4000 & 30 & 30 & 2.88 & 2.88 & 1.04 & 1.52 & 122.5 \\
\hline 8 & $\mathrm{Cr} 4$ & 3500 & 40 & 30 & 5.64 & 5.64 & 1.48 & 1.94 & 122.0 \\
\hline 9 & $\mathrm{Cr} 4$ & 3500 & 50 & 30 & 7.52 & 7.52 & 1.51 & 2.09 & 122.5 \\
\hline 10 & $\mathrm{Cr} 4$ & 3500 & 60 & 30 & 10.03 & 10.03 & 1.61 & 2.25 & 123.5 \\
\hline 11 & $\mathrm{Cr} 4$ & 3500 & 70 & 30 & 6.24 & 6.24 & 1.44 & 2.01 & 121.6 \\
\hline 12 & $\mathrm{Cr} 4$ & 3500 & 60 & 05 & 1.66 & 9.96 & 1.02 & 1.67 & 120.8 \\
\hline 13 & $\mathrm{Cr} 4$ & 3500 & 60 & 15 & 4.30 & 8.60 & 1.18 & 1.72 & 121.2 \\
\hline 14 & $\mathrm{Cr} 4$ & 3500 & 60 & 45 & 10.24 & 6.83 & 1.61 & 2.16 & 121.1 \\
\hline 15 & $\mathrm{Cr} 4$ & 3500 & 60 & 60 & 10.54 & 5.27 & 1.67 & 2.18 & 120.7 \\
\hline $16^{\mathrm{e}}$ & $\mathrm{Cr} 4$ & 3500 & 60 & 30 & 4.88 & 4.88 & 0.98 & 1.86 & 121.3 \\
\hline $17^{\mathrm{f}}$ & $\mathrm{Cr} 4$ & 3500 & 60 & 30 & Trace & - & - & - & - \\
\hline
\end{tabular}

${ }^{a}$ General conditions: $2 \mu \mathrm{mol}$ of $\mathrm{Cr} 4,10 \mathrm{~atm}$ of ethylene, $100 \mathrm{~mL}$ of toluene; ${ }^{\mathrm{b}} 10^{6} \mathrm{~g}(\mathrm{PE}) \cdot \mathrm{mol}^{-1}(\mathrm{Cr}) \cdot \mathrm{h}^{-1}{ }^{\mathrm{c}} \mathrm{M}_{\mathrm{w}}$ : in $\mathrm{kg} \mathrm{mol}^{-1}$, determined by GPC; ${ }^{\mathrm{d}}$ Determined by Differential Scanning Calorimetry (DSC); ${ }^{\mathrm{s}} \mathrm{atm}$ of ethylene; ${ }^{\mathrm{f}} 1 \mathrm{~atm}$ of ethylene.

To investigate the lifetime of the active species in the $\mathrm{Cr} 4 / \mathrm{MAO}$ system, the catalytic screens were conducted over time $(5,15,30,45$ and $60 \mathrm{~min})$ with the reaction temperature maintained at $60{ }^{\circ} \mathrm{C}$ and the $\mathrm{Al} / \mathrm{Cr}$ molar ratio of 3500 (entries 10 and 12-15, Table 2). The highest activity of $10.03 \times 10^{6} \mathrm{~g}(\mathrm{PE}) \mathrm{mol}^{-1}(\mathrm{Cr}) \mathrm{h}^{-1}$ was observed at the $30 \mathrm{~min}$ mark (entry 10, Table 2) while this activity value was similar with that obtained at 5 and $15 \mathrm{~min}$ indicating no obvious induction period needed to generate the active species. Then the catalytic activity gradually decreased with the reaction time extension reaching its lowest value of $5.27 \times 10^{6} \mathrm{~g}(\mathrm{PE}) \mathrm{mol}^{-1}(\mathrm{Cr}) \mathrm{h}^{-1}$ at $60 \mathrm{~min}$ (entry 15, Table 2) 
suggesting that the active species formed slowly after the addition of MAO and underwent progressive deactivation over time [49-53,62-64]. While the obtained polyethylene had increased molecular weight over time illustrating that there were sufficient active species present to maintain chain propagation despite gradual deactivation (Figure 3a) [49-53]. With other reaction parameters maintained at the optimum values, on lowering the ethylene pressure from 10 to $5 \mathrm{~atm}$ the catalytic activity has more than halved (entry 16 vs. entry 10, Table 2). Further reducing the ethylene pressure to 1 atm, only a trace amount of polymer was obtained (entry 17, Table 2), which is in accord with the previous observations for structurally related chromium pre-catalysts [62-64]. These results manifest that high pressure of ethylene is necessary to achieve satisfactory activities consistent with the direct correlation between catalytic activity and ethylene concentration [54-64].

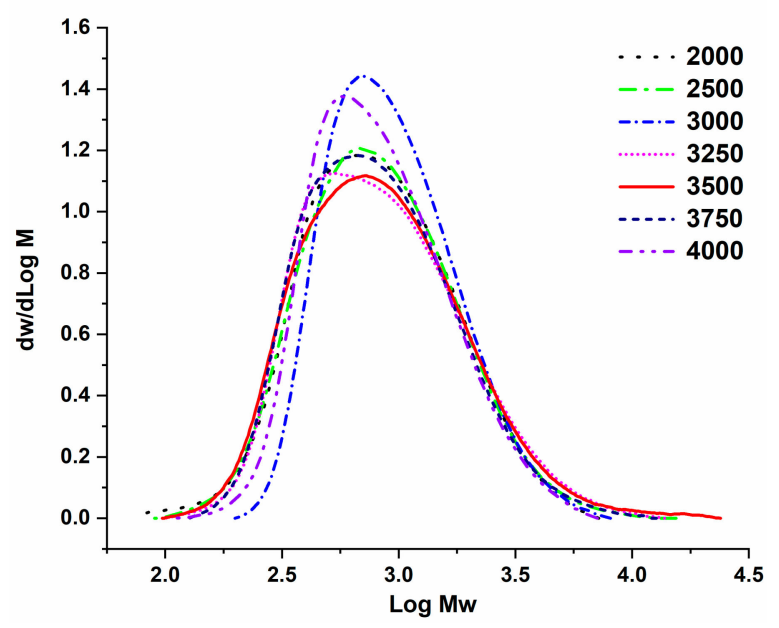

(a)

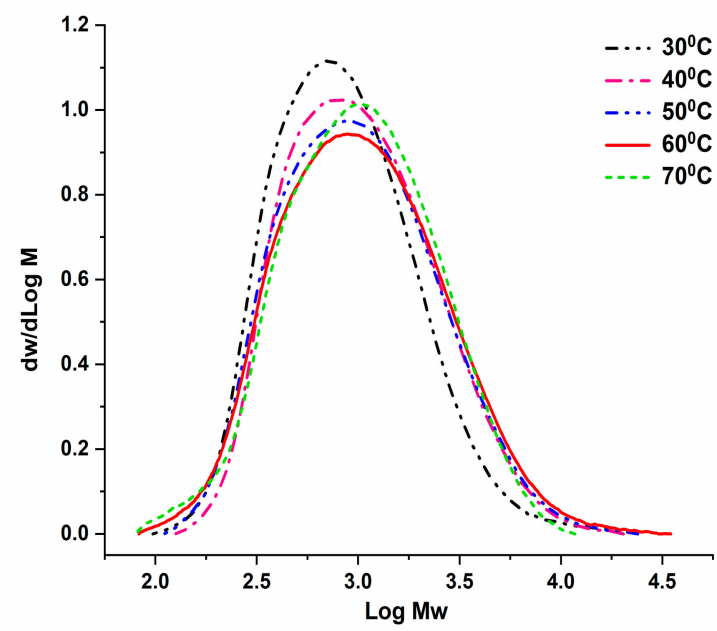

(b)

Figure 2. (a) GPC curves for the polyethylene obtained using $\mathrm{Cr} 4 / \mathrm{MAO}$ at various $\mathrm{Al} / \mathrm{Cr}$ ratios with the reaction temperature fixed at $30^{\circ} \mathrm{C}$ (entries 1-7, Table 2); (b) GPC curves of the polyethylene formed using $\mathrm{Cr} 4 / \mathrm{MAO}$ at different temperatures with the $\mathrm{Al} / \mathrm{Cr}$ molar ratio fixed at 3500 (entries 5 and 8-11, Table 2).

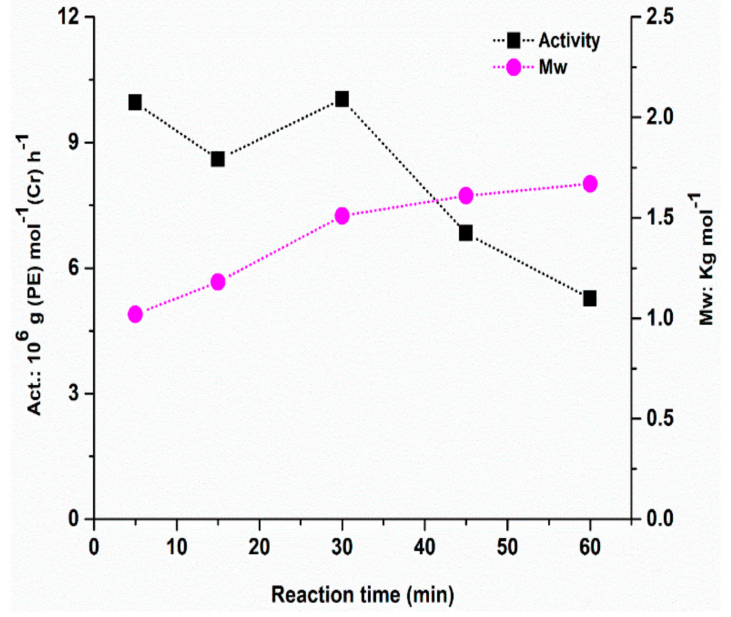

(a)

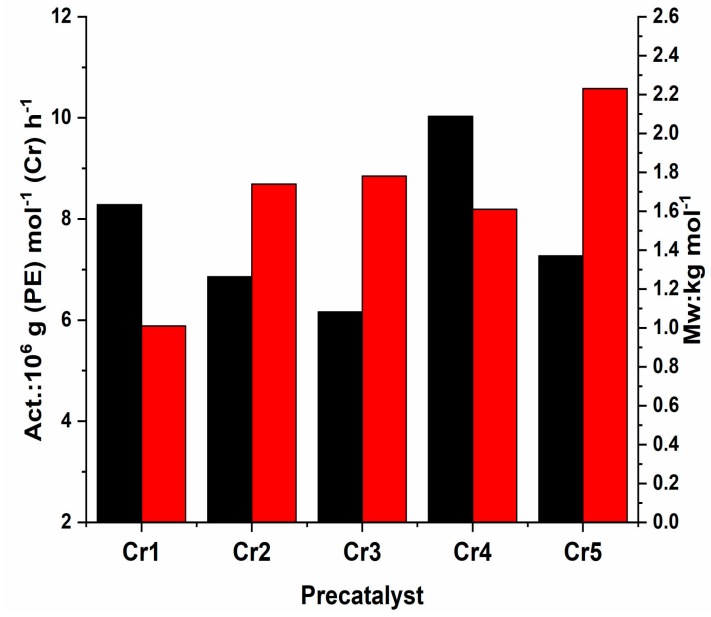

(b)

Figure 3. (a) Activity and $\mathrm{M}_{\mathrm{w}}$ vs. reaction time for Cr4/MAO system (entries 10 and 12-15, Table 2); (b) Comparative activity of $\mathrm{Cr} 1-\mathrm{Cr} 5$ and $\mathrm{M}_{\mathrm{W}}$ of the corresponding polymers (Table 3 ). 
Table 3. Ethylene polymerization with $\mathrm{Cr} 1-\mathrm{Cr} 5 / \mathrm{MAO}^{\mathrm{a}}$.

\begin{tabular}{ccccccc}
\hline Entry & Precatalyst & PE, $\mathbf{g}$ & Activity $^{\mathbf{b}}$ & $\boldsymbol{M}_{\mathbf{w}}{ }^{\mathbf{c}}$ & $\boldsymbol{M}_{\mathbf{w}} / \boldsymbol{M}_{\mathbf{n}}{ }^{\mathbf{c}}$ & $\boldsymbol{T}_{\mathbf{m}}{ }^{\mathbf{d}},{ }^{\circ} \mathbf{C}$ \\
\hline 1 & $\mathbf{C r} 1$ & 8.28 & 8.28 & 1.01 & 1.62 & 121.8 \\
2 & $\mathbf{C r} 2$ & 6.86 & 6.86 & 1.74 & 1.99 & 122.3 \\
3 & $\mathbf{C r} 3$ & 6.16 & 6.16 & 1.78 & 2.03 & 122.9 \\
4 & $\mathbf{C r} 4$ & 10.03 & 10.03 & 1.61 & 2.25 & 123.5 \\
5 & $\mathbf{C r} 5$ & 7.27 & 7.27 & 2.23 & 2.22 & 125.2
\end{tabular}

a General conditions: $2 \mu \mathrm{mol}$ of $\mathrm{Cr}, 10 \mathrm{~atm}$ of ethylene, $100 \mathrm{~mL}$ of toluene, $\mathrm{Al} / \mathrm{Cr}=3500, \mathrm{~T}=60^{\circ} \mathrm{C}, 30 \mathrm{~min}$;

b $10^{6} \mathrm{~g}(\mathrm{PE}) \cdot \mathrm{mol}^{-1}(\mathrm{Cr}) \cdot \mathrm{h}^{-1}{ }^{\mathrm{c}} \mathrm{M}_{\mathrm{W}}$ : in $\mathrm{kg} \mathrm{mol}^{-1}$, determined by GPC; ${ }^{\mathrm{d}}$ Determined by DSC.

\subsubsection{Ethylene Polymerization with the Cr1-Cr5/MAO Using Optimal Reaction Conditions}

With an aim to investigate the influence of structural variations made to the chromium precatalysts on catalyst performance and polymer properties, the remaining four pre-catalysts were investigated for ethylene polymerization under the optimal conditions $\left(\mathrm{Al} / \mathrm{Cr}=3500\right.$, run temperature $=60{ }^{\circ} \mathrm{C}$, run time $=30 \mathrm{~min}$ ) established by $\mathrm{Cr} 4 / \mathrm{MAO}$ (entry 10, Table 2). The activity of these catalysts (Cr1-Cr5) and molecular weight of the obtained polymers were described in Figure $3 b$. High activities in the range of $(6.16-10.03) \times 10^{6} \mathrm{~g}(\mathrm{PE}) \mathrm{mol}^{-1}(\mathrm{Cr}) \mathrm{h}^{-1}$ were observed with the following order: Cr4 [2,4,6-tri(Me)] > Cr1 [(2,6-di(Me)] $>$ Cr5 [2,6-di(Et)-4-Me $)]>$ Cr2 [(2,6-di(Et) $]>$ Cr3 [(2,6-di $\left.\left({ }^{i} \operatorname{Pr}\right)\right]$ (Table 3), which indicates the catalytic activity closely related with both steric and electronic effects imparted by the second $\mathrm{N}$-aryl imine group. $\mathrm{Cr} 3$ containing bulky 2,6-diisopropyl-imine groups was found to exhibit lower catalytic activity as the crowded space around the chromium center led to lower ethylene coordination and insertion rates $[57,62,63,73]$. The electronic effect was reflected in the presence of an electron-donating para-methyl substituent of $\mathrm{Cr} 4$ and $\mathrm{Cr} 5$, which was beneficial to the improvement of catalytic activity when compared with para-hydrogen substituted Cr1 and Cr2, respectively [63]. By comparison with polymerization data recorded for ortho-chloro-substituted chromium complexes, all the chromium complexes in this work generally showed higher catalytic activity producing polyethylene with lower molecular weight [64].

To investigate the microstructural properties of the polyethylenes generated using $\mathrm{Cr} 4 / \mathrm{MAO}$, both DSC and high temperature ${ }^{1} \mathrm{H}$ and ${ }^{13} \mathrm{C}$ NMR spectroscopic measurements were employed. $\mathrm{T}_{\mathrm{m}}$ values of the resultant polymers exceeding $120^{\circ} \mathrm{C}$ indicates the obtained high-density polyethylene possessed highly linear structures (Tables 2 and 3). For further confirming this speculation, a representative sample with the highest yield obtained by $\mathrm{Cr} 4 / \mathrm{MAO}$ at $60^{\circ} \mathrm{C}$ (entry 10, Table 2) was subjected to the ${ }^{1} \mathrm{H}$ and ${ }^{13} \mathrm{C}$ high-temperature spectroscopy (recorded in 1,1,2,2-tetrachloroethane- $d_{2}$ at $100{ }^{\circ} \mathrm{C}$ ) (Figure 4). The prominent singlets at $\delta=1.35$ in the ${ }^{1} \mathrm{H}$ spectrum and $\delta=30.00$ in the ${ }^{13} \mathrm{C}$ spectrum corresponding to the repeating $-\left(\mathrm{CH}_{2}\right)_{n}$ - repeat units again reflected the strict linearity of resultant polyethylene [49-53]. However, there was no evidence of double bonds present in the chain of polymer meaning that no unsatarated polymer formed along a termination pathway involving $\beta$-hydrogen elimination or transfer [51].

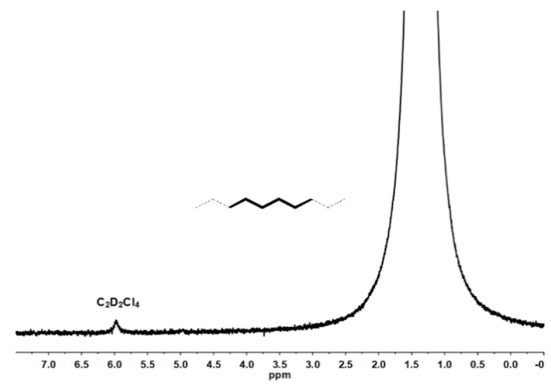

(a)

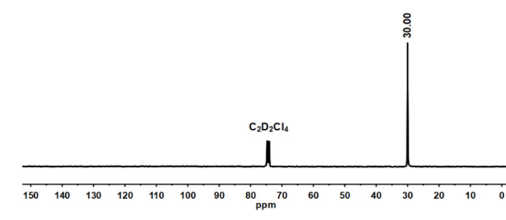

(b)

Figure 4. (a) ${ }^{1} \mathrm{H}-\mathrm{NMR}$ spectrum of the polyethylene obtained by $\mathrm{Cr} 4 / \mathrm{MAO}$ at $60{ }^{\circ} \mathrm{C}$, recorded in 1,1,2,2-tetrachloroethane- $d_{2}$ at $100{ }^{\circ} \mathrm{C}$; (b) ${ }^{13} \mathrm{C}$-NMR spectrum of the polyethylene obtained by $\mathrm{Cr} 4 / \mathrm{MAO}$ at $60^{\circ} \mathrm{C}$, recorded in $1,1,2,2$-tetrachloroethane- $d_{2}$ at $100{ }^{\circ} \mathrm{C}$ (entry 10 , Table 2). 


\subsubsection{Catalytic Evaluation of Cr4/MMAO Catalytic System}

To complement the study performed with MMAO as co-catalyst; the results are collected in Table 4. Once again, $\mathrm{Cr} 4$ was chosen as the test pre-catalyst to allow an optimization of the polymerization parameters. The polymerization was conducted at $10 \mathrm{~atm}$ of ethylene pressure, and the screening results are given in Table 4. Initially, on increasing $\mathrm{Al} / \mathrm{Cr}$ molar ratio from 2000 to 4500 at $30{ }^{\circ} \mathrm{C}$, a maximum activity of $20.14 \times 10^{6} \mathrm{~g}(\mathrm{PE}) \mathrm{mol}^{-1}(\mathrm{Cr}) \mathrm{h}^{-1}$ was found with an $\mathrm{Al} / \mathrm{Cr}$ ratio of 4000 (entry 6, Table 4). Cr4/MMAO generates ca. 3.5-fold higher activity in comparison to Cr4/MAO, similar to observations reported elsewhere [74]. When further raising the amount of co-catalyst, the activity was sharply reduced to $11.14 \times 10^{6} \mathrm{~g}(\mathrm{PE}) \mathrm{mol}^{-1}(\mathrm{Cr}) \mathrm{h}^{-1}$ as a result of the increased chain transfer from the chromium center to aluminum [61]. In addition, the molecular weight distribution $\left(M_{w} / M_{n}\right.$ range $\left.=1.62-2.14\right)$ remained particularly narrow and unimodal, as shown by the GPC curves (Figure 5a).

With the $\mathrm{Al} / \mathrm{Cr}$ molar ratio kept at 4000 and the run time set at $30 \mathrm{~min}$, the reaction temperature had been increased from 20 to $60^{\circ} \mathrm{C}$ (entries 6 and 9-12, Table 4). The best catalytic activity was attained at $30^{\circ} \mathrm{C}$ with a value of $20.14 \times 10^{6} \mathrm{~g}(\mathrm{PE}) \mathrm{mol}^{-1}(\mathrm{Cr}) \mathrm{h}^{-1}$. The differences in optimum polymerization temperature between $\mathrm{Cr} / \mathrm{MAO}$ and $\mathrm{Cr} / \mathrm{MMAO}$ catalytic system may be attributed to the different energy barrier for cocatalysts to activate the chromium precatalyst [56]. At higher temperature, the activity was decreased slowly due to the partially deactivation of the active species [65-69] and lower solubility of ethylene [70-72] (Figure 5b) but nevertheless revealed a good level of $11.76 \times 10^{6} \mathrm{~g}$ (PE) $\mathrm{mol}^{-1}(\mathrm{Cr}) \mathrm{h}^{-1}$ at $60^{\circ} \mathrm{C}$ (entry 12, Table 4). Similar to MAO case, the molecular weight of obtained polyethylene reached a peak up to $1.43 \mathrm{~kg} \mathrm{~mol}^{-1}$ at the optimum temperature which indicates that chain propagation served as the dominant reaction before reaching the optimum temperature $\left(\leq 30^{\circ} \mathrm{C}\right)$ but when further increasing the reaction temperature the higher rate of chain termination resulted in the lower molecular weight of polyethylene [57,65-69].

Table 4. Ethylene polymerization studies with $\mathrm{Cr} 4 / \mathrm{MMAO}^{\mathrm{a}}$.

\begin{tabular}{|c|c|c|c|c|c|c|c|c|c|}
\hline Entry & Cat. & $\mathrm{Al}: \mathrm{Cr}$ & $T,{ }^{\circ} \mathrm{C}$ & $t, \min$ & $\mathrm{PE}, \mathrm{g}$ & Activity $^{b}$ & $M_{\mathrm{w}}^{\mathrm{c}}$ & $M_{w} / M_{\mathrm{n}}{ }^{\mathrm{c}}$ & $T_{m}{ }^{d},{ }^{\circ} \mathrm{C}$ \\
\hline 1 & $\mathrm{Cr} 4$ & 2000 & 30 & 30 & 5.18 & 5.18 & 0.77 & 1.71 & 119.9 \\
\hline 2 & $\mathrm{Cr} 4$ & 2500 & 30 & 30 & 7.44 & 7.44 & 1.09 & 2.01 & 120.0 \\
\hline 3 & $\mathrm{Cr} 4$ & 3000 & 30 & 30 & 12.14 & 12.14 & 1.27 & 2.14 & 120.9 \\
\hline 4 & $\mathrm{Cr} 4$ & 3500 & 30 & 30 & 15.53 & 15.53 & 1.36 & 1.91 & 121.0 \\
\hline 5 & $\mathrm{Cr} 4$ & 3750 & 30 & 30 & 17.51 & 17.51 & 1.38 & 1.95 & 121.7 \\
\hline 6 & $\mathrm{Cr} 4$ & 4000 & 30 & 30 & 20.14 & 20.14 & 1.43 & 1.97 & 122.4 \\
\hline 7 & $\mathrm{Cr} 4$ & 4250 & 30 & 30 & 13.27 & 13.27 & 1.05 & 1.89 & 120.8 \\
\hline 8 & $\mathrm{Cr} 4$ & 4500 & 30 & 30 & 11.14 & 11.14 & 0.78 & 1.62 & 120.5 \\
\hline 9 & $\mathrm{Cr} 4$ & 4000 & 20 & 30 & 13.28 & 13.28 & 0.89 & 1.76 & 120.3 \\
\hline 10 & $\mathrm{Cr} 4$ & 4000 & 40 & 30 & 17.84 & 17.84 & 1.20 & 2.07 & 122.0 \\
\hline 11 & $\mathrm{Cr} 4$ & 4000 & 50 & 30 & 13.63 & 13.63 & 1.07 & 1.80 & 121.5 \\
\hline 12 & $\mathrm{Cr} 4$ & 4000 & 60 & 30 & 11.76 & 11.76 & 1.06 & 1.73 & 120.4 \\
\hline 13 & $\mathrm{Cr} 4$ & 4000 & 30 & 05 & 3.03 & 18.18 & 0.67 & 1.39 & 119.1 \\
\hline 14 & $\mathrm{Cr} 4$ & 4000 & 30 & 15 & 9.52 & 19.04 & 0.73 & 1.52 & 120.3 \\
\hline 15 & $\mathrm{Cr} 4$ & 4000 & 30 & 45 & 22.31 & 14.87 & 1.48 & 1.88 & 120.4 \\
\hline 16 & $\mathrm{Cr} 4$ & 4000 & 30 & 60 & 22.79 & 11.39 & 1.55 & 2.42 & 120.7 \\
\hline $17^{\mathrm{e}}$ & $\mathrm{Cr} 4$ & 4000 & 30 & 30 & 8.56 & 8.56 & 0.76 & 1.71 & 119.4 \\
\hline $18^{\mathrm{f}}$ & $\mathrm{Cr} 4$ & 4000 & 30 & 30 & Trace & - & - & - & - \\
\hline
\end{tabular}

${ }^{a}$ General conditions: $2 \mu \mathrm{mol}$ of $\mathrm{Cr} 4,10 \mathrm{~atm}$ of ethylene, $100 \mathrm{~mL}$ of toluene; ${ }^{\mathrm{b}} 10^{6} \mathrm{~g}(\mathrm{PE}) \cdot \mathrm{mol}^{-1}(\mathrm{Cr}) \cdot \mathrm{h}^{-1}$; $^{\mathrm{c}} \mathrm{M}_{\mathrm{w}}$ : in

$\mathrm{kg} \mathrm{mol}^{-1}$, determined by GPC; ${ }^{\mathrm{d}}$ Determined by DSC; ${ }^{\mathrm{e}} 5 \mathrm{~atm}$ of ethylene; ${ }^{\mathrm{f}} 1 \mathrm{~atm}$ of ethylene.

In the next step, the temperature was kept at $30^{\circ} \mathrm{C}$ and the $\mathrm{Al} / \mathrm{Cr}$ molar ratio at 4000 , the effect of time was investigated by conducting the polymerizations using Cr4/MMAO at 5, 15, 30, 45 and 60 min intervals (entries 6 and 13-16, Table 4) (Figure 6a). Similar with the Cr4/MAO system, the optimal activity of $20.14 \times 10^{6} \mathrm{~g}(\mathrm{PE}) \mathrm{mol}^{-1}(\mathrm{Cr}) \mathrm{h}^{-1}$ was again achieved within $30 \mathrm{~min}$ (entry 6, Table 4). Between 5 to $30 \mathrm{~min}$ the activity was gradually increased, while during the second $30 \mathrm{~min}$ it was 
slowly decreased with the onset of catalyst deactivation [49-53,62-64]. With regard to molecular weight of the resultant polymers, longer reactions were accompanied by an increase in the value of molecular weight from 0.67 to $1.55 \mathrm{~kg} \mathrm{~mol}^{-1}$; this observation can be attributed to stable presence of sufficient active species over longer reaction time during the polymerization process [57]. Reducing the ethylene pressure was also significantly affected the catalytic performance, which was demonstrated by the much lower activity at $5 \mathrm{~atm}$ of $\mathrm{C}_{2} \mathrm{H}_{4}$ and only traced amounts of the polymer were gained at $1 \mathrm{~atm}$ of ethylene (entries 17 and 18, Table 4). Additionally, the molecular weight of the obtained polymer at $5 \mathrm{~atm}$ of ethylene pressure was lower than that achieved at $10 \mathrm{~atm}$ of ethylene pressure, which can be attributed to the slower propagation rate at lower ethylene pressure (entries 6,17 and 18, Table 4) [54-64].

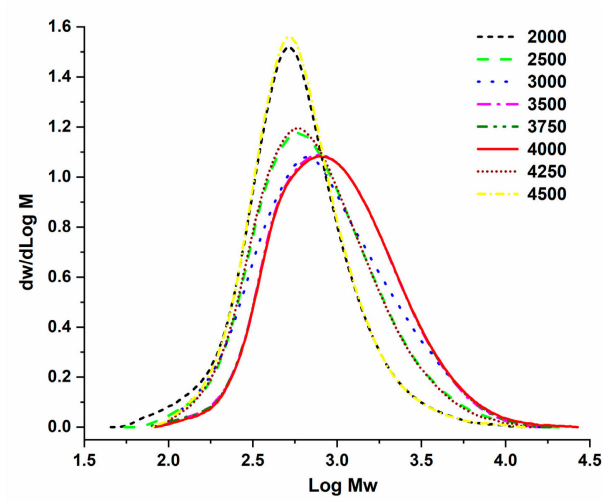

(a)

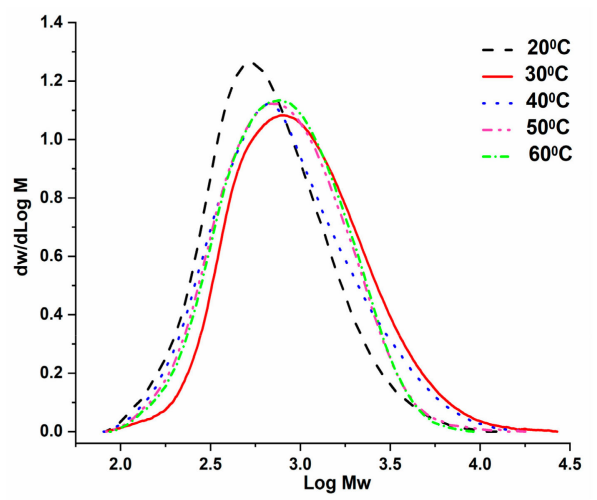

(b)

Figure 5. (a) GPC curves for the polyethylene obtained using $\mathrm{Cr} 4 / \mathrm{MMAO}$ at various $\mathrm{Al} / \mathrm{Cr}$ ratios with the reaction temperature fixed at $30{ }^{\circ} \mathrm{C}$ (entries 1-8, Table 4); (b) GPC curves of the polyethylene formed using Cr4/MMAO at different temperatures with the Al/Cr molar ratio fixed at 4000 (entries 6 and 9-12, Table 4).

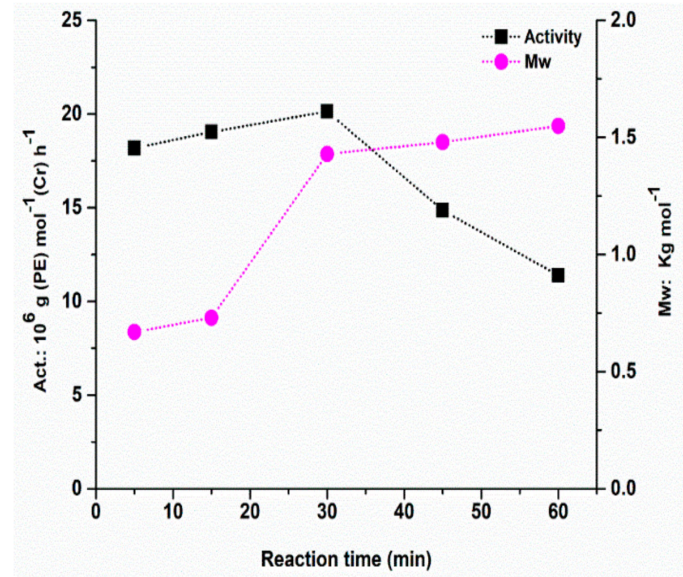

(a)

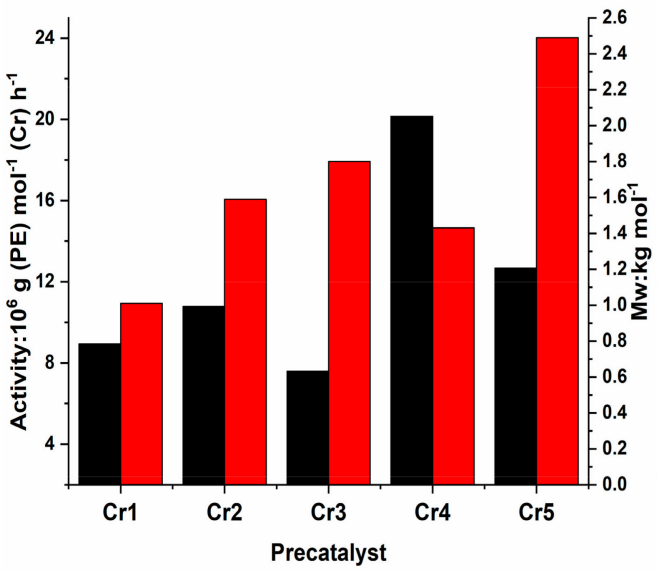

(b)

Figure 6. (a) Activity and $\mathrm{M}_{\mathrm{W}}$ vs. reaction time for Cr4/MMAO system (entries 6 and 13-16, Table 4); (b) Comparative activity of $\mathrm{Cr} 1-\mathrm{Cr} 5$ and $\mathrm{M}_{\mathrm{W}}$ of the corresponding polymers (Table 5).

\subsubsection{Ethylene Polymerization with the Cr1-Cr5/MMAO Using Optimal Reaction Conditions}

Using the favored operating conditions established using $\mathrm{Cr} 4 / \mathrm{MMAO}(\mathrm{Al} / \mathrm{Cr}=4000$, run temperature $=30^{\circ} \mathrm{C}$, run time $=30 \mathrm{~min}$ ), the remaining precatalysts, $\mathrm{Cr} 1-\mathrm{Cr} 3$ and $\mathrm{Cr} 5$, were all evaluated using MMAO as cocatalyst (Table 5). According to the data, all the chromium complexes (Cr1-Cr5) exhibited activities in the range of 7.59-20.14 $\times 10^{6} \mathrm{~g}(\mathrm{PE}) \mathrm{mol}^{-1}(\mathrm{Cr}) \mathrm{h}^{-1}$ (Table 5) which were generally 
higher when compared to $\mathrm{Cr} / \mathrm{MAO}$ catalytic system $\left(6.16-10.03 \times 10^{6} \mathrm{~g}(\mathrm{PE}) \mathrm{mol}^{-1}(\mathrm{Cr}) \mathrm{h}^{-1}\right)(\mathrm{Table} 3)$ highlighting the importance of the aluminoxane activator. The overall activity decreased in the order $\mathrm{Cr} 4$ [2,4,6-tri(Me)] > Cr5 [2,6-di(Et)-4-Me] > Cr2 [2,6-di(Et)] > Cr1 [2,6-di(Me)] > Cr3 [2,6-di $\left.\left({ }^{i} \operatorname{Pr}\right)\right]$ as a result of the combined action of electronic and steric effects of the ligands (Figure 6b) $[57,62,63,73]$. By way of comparison, structurally related chromium precatalysts bearing 2,4-dibenzhydryl-6-chlorophenyl groups displayed relatively lower activity while the most hindered $\mathrm{Cr} 3$ showed lower activity than that in this work (Chart 1) indicating that the solubility of catalyst also affected their catalytic activity [64].

Table 5. Ethylene polymerization with Cr1-Cr5/MMAO ${ }^{\text {a }}$

\begin{tabular}{ccccccc}
\hline Entry & Precatalyst & PE, $\mathbf{g}$ & Activity $^{\mathbf{b}}$ & $\boldsymbol{M}_{\mathbf{w}}{ }^{\mathbf{c}}$ & $\boldsymbol{M}_{\mathbf{w}} / \boldsymbol{M}_{\mathbf{n}}{ }^{\mathbf{c}}$ & $\boldsymbol{T}_{\mathbf{m}}{ }^{\mathbf{d}},{ }^{\circ} \mathbf{C}$ \\
\hline 1 & Cr1 & 8.93 & 8.93 & 1.01 & 1.92 & 120.4 \\
2 & Cr2 & 10.78 & 10.78 & 1.59 & 2.12 & 121.3 \\
3 & Cr3 & 7.59 & 7.59 & 1.80 & 2.01 & 123.5 \\
4 & Cr4 & 20.14 & 20.14 & 1.43 & 1.97 & 122.4 \\
5 & Cr5 & 12.67 & 12.67 & 2.49 & 2.27 & 125.0
\end{tabular}

a General conditions: $2 \mu \mathrm{mol}$ of $\mathrm{Cr}, 10 \mathrm{~atm}$ of ethylene, $100 \mathrm{~mL}$ of toluene, $\mathrm{Al} / \mathrm{Cr}=4000, \mathrm{~T}=30^{\circ} \mathrm{C}, 30 \mathrm{~min}$;

b $10^{6} \mathrm{~g}(\mathrm{PE}) \cdot \mathrm{mol}^{-1}(\mathrm{Cr}) \cdot \mathrm{h}^{-1} ;^{\mathrm{c}} \mathrm{M}_{\mathrm{W}}$ in $\mathrm{kg} \mathrm{mol}^{-1}$, determined by GPC; ${ }^{\mathrm{d}}$ Determined by DSC.

To further study the effect of cocatalyst type on the microstructures of the polymers, the sample achieved by $\mathrm{Cr} 4 / \mathrm{MMAO}$ at $30^{\circ} \mathrm{C}$ (entry 6, Table 4 ) was also measured by high temperature ${ }^{1} \mathrm{H}-\mathrm{NMR}$ and ${ }^{13} \mathrm{C}$ NMR spectroscopic study. Similar with the result in MAO case, the presence of singlet resonances in both the ${ }^{1} \mathrm{H}-\mathrm{NMR}$ spectrum (at $\delta 1.35$, Figure 7a) and the ${ }^{13} \mathrm{C}-\mathrm{NMR}$ spectrum (at $\delta 30.0$, Figure 7b) is characteristic with high linearity polyethylene, corresponding to the methylene $\left(-\mathrm{CH}_{2}-\right)$ repeat unit, again confirmed the formation of highly linear polyethylene which was further corroborated by its high melting temperature $\left(\mathrm{T}_{\mathrm{m}}>119^{\circ} \mathrm{C}\right.$ ) (Figure 7) [49-53].

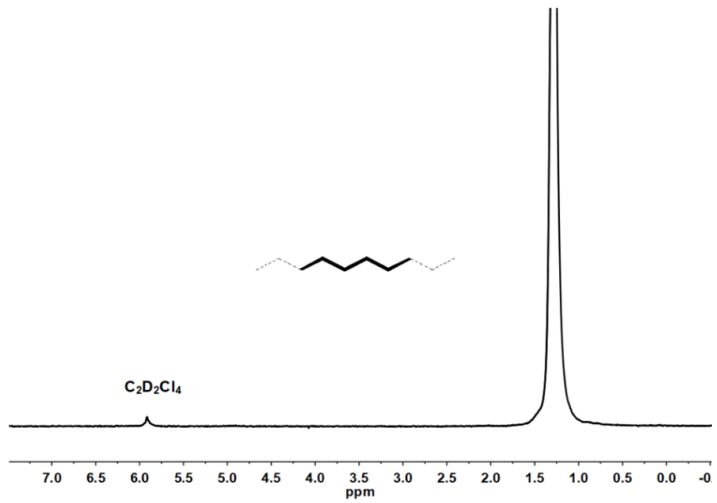

(a)

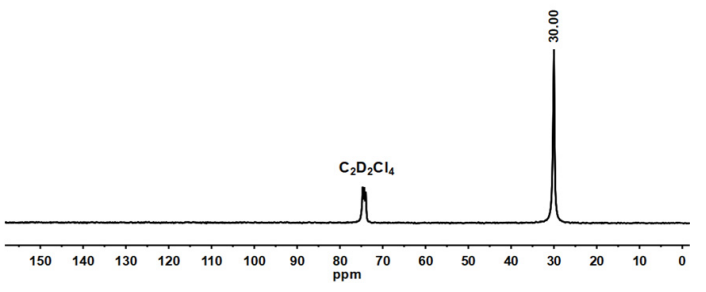

(b)

Figure 7. (a) ${ }^{1} \mathrm{H}-\mathrm{NMR}$ spectrum of the polyethylene obtained by $\mathrm{Cr} 4 / \mathrm{MMAO}$ at $60{ }^{\circ} \mathrm{C}$, recorded in 1,1,2,2-tetrachloroethane- $d_{2}$ at $100{ }^{\circ} \mathrm{C}$; (b) ${ }^{13} \mathrm{C}$-NMR spectrum of the polyethylene obtained by $\mathrm{Cr} 4 / \mathrm{MMAO}$ at $60^{\circ} \mathrm{C}$, recorded in 1,1,2,2-tetrachloroethane- $d_{2}$ at $100{ }^{\circ} \mathrm{C}$.

To allow a comparison of these current chromium precatalysts (G in Chart 1) with the structurally related chromium systems, $\mathbf{E}$ and $\mathbf{F}$ (Chart 1), the optimum activity and the molecular weight as well as the polydisperisity of resultant polymers observed for each precatalyst are depicted in Figure 8. All polymerization tests were performed under their optimum condition at 10 atm $\mathrm{C}_{2} \mathrm{H}_{4}$ over 30 min using MMAO as cocatalyst [62-64]. Inspection of Figure 8 shows that $\mathbf{G}$ exhibited the highest catalytic activity of all four classes highlighting the beneficial effect of strong electro-withdrawing group (ortho-fluoro substitution) on improving catalytic activity of precatalysts [75]. Moreover, the chromium precatalysts E containing 2,6-dibenzhydryl group delivered polyethylene with much higher molecular weight in the lowest yield when compared to $\mathbf{F}$ and $\mathbf{G}$ substituted by 2,4-dibenzhydryl group indicating 
that the requisite steric protection could largely inhibit chain termination as well as chain propagation leading to high molecular weight polymer inefficiently. In this work, the polyethylenes generated using G/MMAO are characteristic of polyethylene waxes displaying the lowest molecular weights (1.0-2.5 kg mol $\mathrm{m}^{-1}$ ) and relatively narrower molecular weight distributions (1.92-2.27) among these four chromium catalysts in Figure 8. Therefore, G/MMAO shows great promise for potential industrial applications in the production of low molecular weight highly linear polyethylene waxes [51,75].

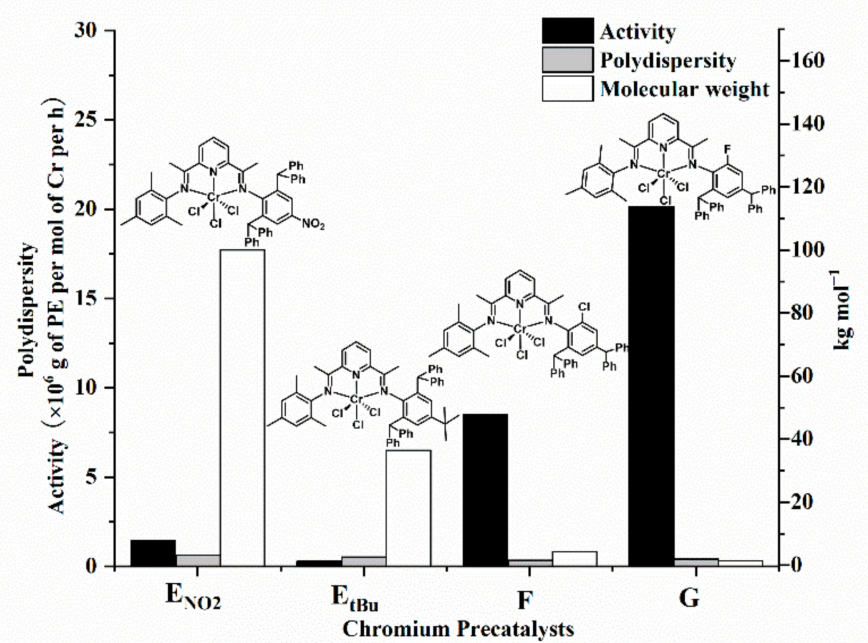

Figure 8. Comparative catalytic performance of Cr4 (G in Chart 1) (entry 4, Table 5) with structrually related chromium-containing $\mathbf{E}_{\mathrm{NO} 2}$ [62], $\mathbf{E}_{\mathbf{t B u}}$ [63] and $\mathbf{F}$ [64] (Chart 1); all polymerizations were recorded at 10 atm $\mathrm{C}_{2} \mathrm{H}_{4}, 30$ min using MMAO as co-catalyst.

\section{Materials and Methods}

\subsection{General Considerations}

The air- and moisture-sensitive compounds were synthesized and handled under nitrogen atmosphere using standard Schlenk techniques. Prior to use, toluene was refluxed over sodium under nitrogen for $10 \mathrm{~h}$. The cocatalysts, methylaluminoxane (MAO, 1.46 M Al solution in toluene) and modified methylaluminoxane (MMAO, 2.00 M Al solution in n-heptane), were purchased from Albemarle Corp. (Baton Rouge, LA, USA). High-purity ethylene was purchased from Beijing Yanshan Petrochemical Co. (Beijing, China) and used as received. Other reagents were purchased from Aldrich (Beijing, China), Acros (Beijing, China) or Beijing Chemicals (Beijing, China). A Bruker Avance III $400 \mathrm{HD}$ instrument (Bruker, Fällanden, Switzerland) was used to record the ${ }^{1} \mathrm{H}$ - and ${ }^{13} \mathrm{C}-\mathrm{NMR}$ spectra of compounds and ligands at ambient temperature using TMS as an internal standard. The ${ }^{1} \mathrm{H}-$ and ${ }^{13} \mathrm{C}$-NMR spectra of the resultant polyethylene were recorded on a Bruker DMX $300 \mathrm{MHz}$ instrument (Bruker, Fällanden, Switzerland) at $100{ }^{\circ} \mathrm{C}$ using the deuterated 1,1,2,2-tetrachloroethane as the deuterium reagent. IR spectra were conducted on a System 2000 FT-IR spectrometer (Perkin-Elmer, Waltham, MA, USA) and elemental analysis (C, H, and N) was carried out using a Thermo Flash Smart EA microanalyzer (Thermo Fisher Scientific, Waltham, MA, USA). The molecular weight $\left(\mathrm{M}_{\mathrm{w}}\right)$ and molecular weight distributions $\left(\mathrm{M}_{\mathrm{W}} / \mathrm{M}_{\mathrm{n}}\right)$ of resultant polyethylenes were determined by the Agilent PL-GPC220 GPC/SEC high-temperature system at $150{ }^{\circ} \mathrm{C}$ with 1,2,4-trichlorobenzene (TCB) as eluent

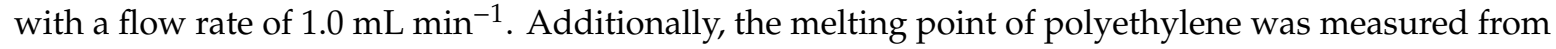
the fourth scanning run by the PerkinElmer TA-Q2000 differential scanning calorimetry (DSC) analyzer (TA Instruments, New Castle, DE, USA) under a nitrogen atmosphere. 


\subsection{Synthesis of 2-Acetyl-6-(1-(2,4-dibenzhydryl-6-fluorophenylimino)ethyl)pyridine (1) and Ligands L1-L5}

\subsubsection{Synthesis of 2-Acetyl-6-(1-(2,4-dibenzhydryl-6-fluorophenylimino)ethyl)pyridine (1)}

The catalytic amount $p$-toluenesulfonic acid $(20 \%$ by mol) was added to the mixed suspension of 2,6-diacetylpyridine ( $4.08 \mathrm{~g}, 25 \mathrm{mmol}$ ) and 2,4-dibenzhydryl-6-fluoroaniline (11.09 g, $25 \mathrm{mmol}$ ) in ortho-xylene $(150 \mathrm{~mL})$. After $10 \mathrm{~h}$ stirring at refluxing temperature, the reaction mixture was filtered in the hot condition and all the volatile solvent was removed by a vacuum pump. Subsequently, the impurities were removed by basic alumina column chromatography using petroleum ether/ethyl acetate $(25 / 1 \mathrm{v} / \mathrm{v})$ as an eluent, yielding product 1 as a light-yellow powder $(4.12 \mathrm{~g}, 28 \%)$. Anal. Calcd. for $\mathrm{C}_{41} \mathrm{H}_{33} \mathrm{FN}_{2} \mathrm{O}$ (588.73): $\mathrm{H}, 5.65 ; \mathrm{C}, 83.65 ; \mathrm{N}, 4.76$. Found: $\mathrm{H}, 5.76 ; \mathrm{C}, 83.47 ; \mathrm{N}, 4.77$. ${ }^{1} \mathrm{H}-\mathrm{NMR}$ $\left(\mathrm{CDCl}_{3}, 400 \mathrm{MHz}, \mathrm{TMS}\right): \delta 8.12\left(\mathrm{~d}, J=8.0 \mathrm{~Hz}, 2 \mathrm{H}, \mathrm{Py}-\mathrm{H}_{\mathrm{m}}\right), 7.88\left(\mathrm{t}, J=7.6 \mathrm{~Hz}, 1 \mathrm{H}, \mathrm{Py}-\mathrm{H}_{\mathrm{p}}\right), 7.81(\mathrm{~s}, 2 \mathrm{H}$, aryl-H), 7.28-7.21 (m, 12H, aryl-H), 7.12-6.96 (m, 8H, aryl-H), $5.27\left(\mathrm{~s}, 2 \mathrm{H}, \mathrm{CHPh}_{2}\right), 2.63\left(\mathrm{~s}, 3 \mathrm{H}, \mathrm{O}=\mathrm{CCH}_{3}\right)$, 1.08 (s, 3H, N=CCH 3$) .{ }^{13} \mathrm{C}-\mathrm{NMR}\left(\mathrm{CDCl}_{3}, 100 \mathrm{MHz}, \mathrm{TMS}\right): \delta 199.8,169.3,153.9,153.6,152.6,143.5,141.7$, 140.5, 136.3, 133.6, 129.6, 129.1, 128.2, 126.6, 126.7, 124.5, 123.6, 122.9, 52.1, 25.2, 17.2. FT-IR $\left(\mathrm{cm}^{-1}\right)$ : $3026(\mathrm{w}), 2927(\mathrm{~m}), 1698\left(v_{\mathrm{C}=\mathrm{O}}, \mathrm{s}\right), 1655\left(v_{\mathrm{C}=\mathrm{N}}, \mathrm{s}\right), 1579(\mathrm{~m}), 1513(\mathrm{~s}), 1491(\mathrm{~m}), 1447(\mathrm{~s}), 1357(\mathrm{~s}), 1324(\mathrm{~s})$, $1229(\mathrm{~s}), 1152(\mathrm{w}), 1117(\mathrm{w}), 1079(\mathrm{~s}), 1027(\mathrm{~m}), 996(\mathrm{w}), 912(\mathrm{~m}), 812(\mathrm{~s}), 766(\mathrm{w}), 695(\mathrm{~s})$.

3.2.2. Synthesis of 2-(1-(2,4-Dibenzhydryl-6-fluorophenylimino)ethyl)-6-(1-(2,6-dimethylphenylimino)ethyl)pyridine (L1)

In a two neck round bottom flask, the solution of 2-acetyl-6-(1-(2,4- dibenzhydryl6-fluorophenylimino)ethyl)pyridine $(2.06 \mathrm{~g}, 3.50 \mathrm{mmol})$ and $p$-toluenesulfonic acid $(20 \%$ by mol) in ortho-xylene $(40 \mathrm{~mL})$ was added and refluxed at $145^{\circ} \mathrm{C}$. Subsequently, 2,6-dimethylaniline $(0.42 \mathrm{~g}$, $3.50 \mathrm{mmol}$ ) was added dropwise into the reaction solution. After $10 \mathrm{~h}$, all the volatile solvent was removed by a vacuum pump and the residue was purified by basic alumina column chromatography using petroleum ether/ethyl acetate (125/1) as an eluent affording $\mathbf{L 1}$ as a light-yellow powder $(0.44 \mathrm{~g}$, 18\%). Anal. Calcd. for $\mathrm{C}_{49} \mathrm{H}_{42} \mathrm{FN}_{3}$ (691.89): $\mathrm{H}, 6.12 ; \mathrm{C}, 85.06 ; \mathrm{N}, 6.07$. Found: $\mathrm{H}, 6.26 ; \mathrm{C}, 84.80 ; \mathrm{N}, 5.87$. ${ }^{1} \mathrm{H}-\mathrm{NMR}\left(\mathrm{CDCl}_{3}, 400 \mathrm{MHz}, \mathrm{TMS}\right): \delta 8.46\left(\mathrm{~d}, J=8.0 \mathrm{~Hz}, 1 \mathrm{H}, \mathrm{Py}-\mathrm{H}_{\mathrm{m}}\right), 8.35\left(\mathrm{~d}, J=7.6 \mathrm{~Hz}, 1 \mathrm{H}, \mathrm{Py}-\mathrm{H}_{\mathrm{m}}\right)$, $7.90\left(\mathrm{t}, J=16.0 \mathrm{~Hz}, 1 \mathrm{H}, \mathrm{Py}-\mathrm{H}_{\mathrm{p}}\right), 7.30-6.79(\mathrm{~m}, 23 \mathrm{H}, \mathrm{Ar}-\mathrm{H}), 6.77(\mathrm{~d}, J=11.2 \mathrm{~Hz}, 1 \mathrm{H}, \mathrm{Ar}-\mathrm{H}), 6.63(\mathrm{~s}, 1 \mathrm{H}$, $\mathrm{Ar}-\mathrm{H}), 5.59\left(\mathrm{~s}, 1 \mathrm{H}, \mathrm{CHPh}_{2}\right), 5.42\left(\mathrm{~s}, 1 \mathrm{H}, \mathrm{CHPh}_{2}\right), 2.19\left(\mathrm{~s}, 3 \mathrm{H}, \mathrm{N}=\mathrm{CCH}_{3}\right), 2.08\left(\mathrm{~s}, 6 \mathrm{H}, 2 \times \mathrm{CH}_{3}\right), 1.87$ (s, 3H, N=CCH 3$) .{ }^{13} \mathrm{C}-\mathrm{NMR}\left(\mathrm{CDCl}_{3}, 100 \mathrm{MHz}, \mathrm{TMS}\right): \delta 170.93,167.22,155.03,154.88,151.94,149.52$, $148.74,143.69,142.56,140.03,139.97,137.44,136.72,135.01,134.87,129.45,129.29,128.31,128.17,127.89$, 126.37, 126.19, 125.44, 123.02, 122.43, 122.23, 114.86, 114.64, 56.16, 52.10, 17.96, 16.81, 16.79, 16.42. FT-IR $\left(\mathrm{cm}^{-1}\right)$ : $3027(\mathrm{w}), 2937(\mathrm{w}), 1643\left(v_{\mathrm{C}=\mathrm{N}}, \mathrm{s}\right), 1568(\mathrm{w}), 1496(\mathrm{w}), 1454(\mathrm{~s}), 1365(\mathrm{~s}), 1328(\mathrm{w}), 1298(\mathrm{w}), 1250$ (s), $1207(\mathrm{~m}), 1121(\mathrm{~s}), 1030(\mathrm{w}), 857(\mathrm{w}), 765(\mathrm{~s})$.

3.2.3. Synthesis of 2-(1-(2,4-Dibenzhydryl-6-fluorophenylimino)ethyl)-6-(1-(2,6-diethylphenylimino) ethyl)pyridine (L2)

Based on the procedure and half molar ratio that were used for the synthesis of L1, L2 was prepared as a light-yellow powder $(0.23 \mathrm{~g}, 18 \%)$. Anal. Calcd. for $\mathrm{C}_{51} \mathrm{H}_{46} \mathrm{FN}_{3}(719.95): \mathrm{H}, 6.44 ; \mathrm{C}, 85.08$; $\mathrm{N}$, 5.84. Found: $\mathrm{H}, 6.58 ; \mathrm{C}, 84.75 ; \mathrm{N}, 5.82 .{ }^{1} \mathrm{H}-\mathrm{NMR}\left(\mathrm{CDCl}_{3}, 400 \mathrm{MHz}, \mathrm{TMS}\right): \delta 8.42(\mathrm{~d}, J=8.0 \mathrm{~Hz}, 1 \mathrm{H}$, Py- $\left.\mathrm{H}_{\mathrm{m}}\right), 8.32\left(\mathrm{~d}, J=7.6 \mathrm{~Hz}, 1 \mathrm{H}, \mathrm{Py}-\mathrm{H}_{\mathrm{m}}\right), 7.88\left(\mathrm{t}, J=15.6 \mathrm{~Hz}, 1 \mathrm{H}, \mathrm{Py}-\mathrm{H}_{\mathrm{p}}\right), 7.28-6.97(\mathrm{~m}, 23 \mathrm{H}, \mathrm{Ar}-\mathrm{H})$, $6.75(\mathrm{~s}, 1 \mathrm{H}, \mathrm{Ar}-\mathrm{H}), 6.60(\mathrm{~s}, 1 \mathrm{H}, \mathrm{Ar}-\mathrm{H}), 5.59\left(\mathrm{~s}, 1 \mathrm{H}, \mathrm{CHPh}_{2}\right), 5.43$ (s, $\left.1 \mathrm{H}, \mathrm{CHPh}_{2}\right), 2.51-2.23(\mathrm{~m}, 4 \mathrm{H}$, $\left.2 \times \mathrm{CH}_{2} \mathrm{CH}_{3}\right), 2.17\left(\mathrm{~s}, 3 \mathrm{H}, \mathrm{N}=\mathrm{CCH}_{3}\right), 1.85\left(\mathrm{~s}, 3 \mathrm{H}, \mathrm{N}=\mathrm{CCH}_{3}\right), 1.20-1.11\left(\mathrm{~m}, 6 \mathrm{H}, 2 \times \mathrm{CH}_{2} \mathrm{CH}_{3}\right) .{ }^{13} \mathrm{C}-\mathrm{NMR}$ ( $\mathrm{CDCl}_{3}, 100 \mathrm{MHz}$, TMS): $\delta$ 169.92, 165.90, 154.00, 153.84, 146.74, 142.64, 141.52, 138.98, 138.91, 136.38, 135.70, 133.97, 130.15, 128.41, 128.25, 127.26, 127.13, 125.33, 125.15, 124.89, 122.27, 121.35, 121.16, 113.81, 113.60, 55.11, 51.01, 23.55, 15.74, 12.69. FT-IR $\left(\mathrm{cm}^{-1}\right)$ : $3024(\mathrm{w}), 2930(\mathrm{w}), 1638\left(v_{\mathrm{C}=\mathrm{N}}, \mathrm{s}\right), 1567(\mathrm{w})$, $1492(\mathrm{w}), 1449$ (s), 1365 (s), $1325(\mathrm{w}), 1296(\mathrm{w}), 1243$ (s), 1199 (m), 1118 (s), 1028 (w), $854(\mathrm{w}), 764$ (s). 
3.2.4. Synthesis of 2-(1-(2,4-Dibenzhydryl-6-fluorophenylimino)ethyl)-6-(1-(2,6-diisopropylphenyl imino)ethyl)pyridine (L3)

Based on the procedure and half molar ratio that were used for the synthesis of L1, L3 was prepared as a light-yellow powder $(0.20 \mathrm{~g}, 15 \%)$. Anal. Calcd. for $\mathrm{C}_{53} \mathrm{H}_{50} \mathrm{FN}_{3}$ (748.00): $\mathrm{H}, 6.74 ; \mathrm{C}, 85.10$; $\mathrm{N}$, 5.62. Found: $\mathrm{H}, 6.92 ; \mathrm{C}, 84.96 ; \mathrm{N}, 5.55 .{ }^{1} \mathrm{H}-\mathrm{NMR}\left(\mathrm{CDCl}_{3}, 400 \mathrm{MHz}, \mathrm{TMS}\right): \delta 8.42(\mathrm{~d}, J=8.0 \mathrm{~Hz}, 1 \mathrm{H}$, Py- $\left.\mathrm{H}_{\mathrm{m}}\right), 8.32\left(\mathrm{~d}, J=8.0 \mathrm{~Hz}, 1 \mathrm{H}, \mathrm{Py}-\mathrm{H}_{\mathrm{m}}\right), 7.88\left(\mathrm{t}, J=15.6 \mathrm{~Hz}, 1 \mathrm{H}, \mathrm{Py}-\mathrm{H}_{\mathrm{p}}\right), 7.28-6.76(\mathrm{~m}, 23 \mathrm{H}, \mathrm{Ar}-\mathrm{H})$, 6.75 (s, 1H, Ar-H), 6.61 (s, 1H, Ar-H), 5.59 (s, 1H, Ar-H), 5.43 (s, 1H, Ar-H), 2.79-2.72 (m, 2H, CH(CH $\left.\mathrm{CH}_{2}\right)$, $2.19\left(\mathrm{~s}, 3 \mathrm{H}, \mathrm{N}=\mathrm{CCH}_{3}\right), 1.85\left(\mathrm{~d}, \mathrm{~J}=12.0 \mathrm{~Hz}, 3 \mathrm{H}, \mathrm{N}=\mathrm{CCH}_{3}\right), 1.20-1.14\left(\mathrm{~m}, 12 \mathrm{H}, \mathrm{CH}\left(\mathrm{CH}_{3}\right)_{2}\right) .{ }^{13} \mathrm{C}-\mathrm{NMR}$ $\left(\mathrm{CDCl}_{3}, 100 \mathrm{MHz}, \mathrm{TMS}\right): \delta 169.93,165.92,154.01,153.88,145.44,142.65,141.44,136.38,135.69,134.77$, $133.85,128.41,128.25,127.27,127.13,125.33,125.15,122.53,121.96,121.33,121.20,113.81,113.60,55.12$, 51.04, 27.26, 22.18, 21.87, 16.01, 15.79. FT-IR $\left(\mathrm{cm}^{-1}\right)$ : $3024(\mathrm{w}), 2922(\mathrm{w}), 1643\left(v_{\mathrm{C}=\mathrm{N}}, \mathrm{s}\right), 1571(\mathrm{w})$, 1493 (w), 1453 (s), 1361 (s), 1321 (w), 1300 (w), 1254 (s), 1205 (m), 1122 (s), 1032 (w), 849 (w), 765 (s).

3.2.5. Synthesis of 2-(1-(2,4-Dibenzhydryl-6-fluorophenylimino)ethyl)-6-(1-(mesitylimino)ethyl) pyridine (L4)

Based on the procedure and half molar ratio that were used for the synthesis of L1, L4 was prepared as a light-yellow powder $\left(0.23 \mathrm{~g}, 20 \%\right.$ ). Anal. Calcd. for $\mathrm{C}_{50} \mathrm{H}_{44} \mathrm{FN}_{3}$ (705.92): $\mathrm{H}, 6.28 ; \mathrm{C}, 85.07$; $\mathrm{N}$, 5.95. Found: $\mathrm{H}, 6.52 ; \mathrm{C}, 84.74 ; \mathrm{N}, 5.79 .{ }^{1} \mathrm{H}-\mathrm{NMR}\left(\mathrm{CDCl}_{3}, 400 \mathrm{MHz}, \mathrm{TMS}\right): \delta 8.42(\mathrm{~d}, J=8.0 \mathrm{~Hz}, 1 \mathrm{H}$, Py- $\left.\mathrm{H}_{\mathrm{m}}\right), 8.31\left(\mathrm{~d}, J=7.6 \mathrm{~Hz}, 1 \mathrm{H}, \mathrm{Py}-\mathrm{H}_{\mathrm{m}}\right), 7.87\left(\mathrm{t}, J=15.6 \mathrm{~Hz}, 1 \mathrm{H}, \mathrm{Py}-\mathrm{H}_{\mathrm{p}}\right), 7.28-6.89$ (m, 22H, Ar-H), $6.76(\mathrm{~d}, J=10.8 \mathrm{~Hz}, 1 \mathrm{H}, \mathrm{Ar}-\mathrm{H}), 6.60$ (s, 1H, Ar-H), 5.59 (s, 1H, Ar-H), 5.43 (s, 1H, CHPh $), 2.30$ (s, 3H, $\left.\mathrm{Ar}-\mathrm{CH}_{3}\right), 2.16\left(\mathrm{~s}, 3 \mathrm{H}, \mathrm{N}=\mathrm{CCH}_{3}\right), 2.01\left(\mathrm{~s}, 6 \mathrm{H}, 2 \times \mathrm{CH}_{3}\right), 1.84\left(\mathrm{~s}, 3 \mathrm{H}, \mathrm{N}=\mathrm{CCH}_{3}\right) .{ }^{13} \mathrm{C}-\mathrm{NMR}\left(\mathrm{CDCl}_{3}\right.$, $100 \mathrm{MHz}$, TMS): $\delta$ 169.91, 166.36, 154.12, 153.80, 150.90, 148.48, 145.19, 142.65, 141.52, 138.97, 138.91, 136.41, 135.64, 133.98, 133.84, 131.16, 128.40, 128.25, 127.52, 127.26, 127.13, 125.33, 125.14, 124.23, 121.31, 121.18, 113.81, 113.59, 55.11, 51.03, 19.71, 16.84, 15.76, 15.74, 15.32. FT-IR (cm $\left.{ }^{-1}\right): 3022(\mathrm{w}), 2911(\mathrm{w})$, $1640\left(v_{\mathrm{C}=\mathrm{N}}, \mathrm{s}\right), 1567(\mathrm{w}), 1493(\mathrm{w}), 1472(\mathrm{~s}), 1365(\mathrm{~s}), 1327(\mathrm{w}), 1297(\mathrm{w}), 1255(\mathrm{~s}), 1217(\mathrm{~m}), 1119(\mathrm{~s})$, $1028(\mathrm{w}), 854(\mathrm{w}), 738(\mathrm{~s})$.

3.2.6. Synthesis of 2-(1-(2,4-Dibenzhydryl-6-fluorophenylimino)ethyl)-6-(1-(2,6-diethyl-4-methylphenyl imino)ethyl)pyridine (L5)

Based on the procedure and half molar ratio that were used for the synthesis of L1, L5 was prepared as a light-yellow powder $(0.19 \mathrm{~g}, 15 \%)$. Anal. Calcd. for $\mathrm{C}_{52} \mathrm{H}_{48} \mathrm{FN}_{3}$ (733.98): $\mathrm{H}, 6.59 ; \mathrm{C}, 85.09$; $\mathrm{N}$, 5.73. Found: $\mathrm{H}, 6.53 ; \mathrm{C}, 84.80 ; \mathrm{N}, 5.80 .{ }^{1} \mathrm{H}-\mathrm{NMR}\left(\mathrm{CDCl}_{3}, 400 \mathrm{MHz}, \mathrm{TMS}\right): \delta 8.42(\mathrm{~d}, J=8.0 \mathrm{~Hz}, 1 \mathrm{H}$, Py- $\left.\mathrm{H}_{\mathrm{m}}\right), 8.33\left(\mathrm{~d}, J=7.6 \mathrm{~Hz}, 1 \mathrm{H}, \mathrm{Py}-\mathrm{H}_{\mathrm{m}}\right), 7.88\left(\mathrm{t}, J=15.6 \mathrm{~Hz}, 1 \mathrm{H}, \mathrm{Py}-\mathrm{H}_{\mathrm{p}}\right), 7.29-6.94(\mathrm{~m}, 22 \mathrm{H}, \mathrm{Ar}-\mathrm{H})$, $6.76(\mathrm{~d}, J=10.4 \mathrm{~Hz}, 1 \mathrm{H}, \mathrm{Ar}-\mathrm{H}), 6.62$ (s, 1H, Ar-H), 5.60 (s, 1H, CHPh $), 5.44\left(\mathrm{~s}, 1 \mathrm{H}, \mathrm{CHPh}_{2}\right), 2.44-2.27$ $\left(\mathrm{m}, 7 \mathrm{H}, 2 \times \mathrm{CH}_{2} \mathrm{CH}_{3}, \mathrm{~N}=\mathrm{CCH}_{3}\right), 2.18\left(\mathrm{~s}, 3 \mathrm{H}, \mathrm{N}=\mathrm{CCH}_{3}\right), 1.85\left(\mathrm{~s}, 3 \mathrm{H}, \mathrm{CH}_{3}\right), 1.14\left(\mathrm{~m}, 6 \mathrm{H}, 2 \times \mathrm{CH}_{2} \mathrm{CH}_{3}\right)$. ${ }^{13} \mathrm{C}-\mathrm{NMR}\left(\mathrm{CDCl}_{3}, 100 \mathrm{MHz}, \mathrm{TMS}\right): \delta$ 169.95, 166.07, 154.13, 153.79, 150.89, 148.47, 144.22, 142.64, 141.52, $138.96,138.89,136.39,135.65,133.99,133.85,131.37,130.04,128.40,128.24,127.26,127.12,125.63,125.32$, 125.14, 121.26, 121.14, 113.80, 113.59, 55.10, 51.03, 23.54, 19.98, 15.77, 15.74, 15.67, 12.81. FT-IR (cm $\left.{ }^{-1}\right)$ : $3026(w), 2932(w), 1638\left(v_{C=N}, s\right), 1566(w), 1493(w), 1455(s), 1365(s), 1325(w), 1296(w), 1261(s)$, $1207(\mathrm{~m}), 1148(\mathrm{~s}), 1026(\mathrm{w}), 855(\mathrm{w}), 739(\mathrm{~s})$.

\subsection{Synthesis of Chromium Complexes Cr1-Cr5}

3.3.1. Synthesis of 2-(1-(2,4-Dibenzhydryl-6-fluorophenylimino)ethyl)-6-(1-(2,6-dimethylphenyl imino)ethyl)pyridylchromium(III) chloride (Cr1)

$\mathrm{CrCl}_{3} \cdot 3 \mathrm{THF}(0.07 \mathrm{~g}, 0.20 \mathrm{mmol})$ was added to the dichloromethane solution $(10 \mathrm{~mL})$ of 2-(1-(2,4-dibenzhydryl-6-fluorophenylimino)ethyl)-6-(1-(2,6-dimethylphenylimino)ethyl)pyridine $(0.14 \mathrm{~g}, 0.20 \mathrm{mmol})$. This mixture was stirred at room temperature for $10 \mathrm{~h}$ giving a green suspension. Excess of diethyl ether $(20 \mathrm{~mL})$ was poured into the concentrated reaction mixture and the resulting precipitate was collected by filtration, washed with diethyl ether $(3 \times 5 \mathrm{~mL})$ and dried under reduced 
pressure to give $\mathrm{Cr} 1$ as green powder $(0.14 \mathrm{~g}, 83 \%)$. Anal. calcd. for $\mathrm{C}_{49} \mathrm{H}_{42} \mathrm{Cl}_{3} \mathrm{CrFN}_{3}(850.24)$ : $\mathrm{H}$, 4.98; C, 69.22; N, 4.94; Found: H, 4.99; C, 68.97; N, 5.00. FT-IR (cm $\left.{ }^{-1}\right): 3062(\mathrm{~m}), 3024(\mathrm{~m}), 2959(\mathrm{~m}), 2916(\mathrm{~m})$, $1694(\mathrm{w}), 1614\left(\mathrm{~m}, \mathrm{v}_{\mathrm{C}=\mathrm{N}}\right), 1576(\mathrm{~m}), 1492(\mathrm{~m}), 1472(\mathrm{~m}), 1448(\mathrm{~m}), 1426(\mathrm{w}), 1369(\mathrm{w}), 1323(\mathrm{w}), 1268(\mathrm{~m})$, $1214(\mathrm{~m}), 1174(\mathrm{~m}), 1095(\mathrm{~m}), 1035(\mathrm{~m}), 999(\mathrm{~m}), 913(\mathrm{w}), 847(\mathrm{w}), 814(\mathrm{~m}), 774(\mathrm{~m}), 743(\mathrm{~m}), 699$ (s), $658(w)$.

3.3.2. Synthesis of 2-(1-(2,4-Dibenzhydryl-6-fluorophenylimino)ethyl)-6-(1-(2,6-dimethylphenyl imino)ethyl)pyridylchromium(III) chloride (Cr2)

Using similar synthetic procedure and molar ratio described for the synthesis of Cr1, Cr2 was prepared by reacting 2-(1-(2,4-dibenzhydryl-6-fluorophenylimino)ethyl)-6-(1-(2,6-diethylphenyl imino)ethyl)pyridine $(0.14 \mathrm{~g}, 0.20 \mathrm{mmol})$ with $\mathrm{CrCl}_{3} .3 \mathrm{THF}(0.07 \mathrm{~g}, 0.20 \mathrm{mmol})$ and collected as a light green powder $(0.14 \mathrm{~g}, 80 \%)$. Anal. calcd. for $\mathrm{C}_{51} \mathrm{H}_{46} \mathrm{Cl}_{3} \mathrm{CrFN}_{3}$ (878.29): $\mathrm{H}, 5.28 ; \mathrm{C}, 69.74 ; \mathrm{N}, 4.78$; Found: H, 5.28; C, 69.49; N, 4.88. FT-IR (cm $\left.{ }^{-1}\right): 3058(\mathrm{~m}), 3020(\mathrm{~m}), 2965(\mathrm{~m}), 2917$ (m), 1697 (w), $1614\left(\mathrm{~m}, v_{\mathrm{C}=\mathrm{N}}\right), 1576(\mathrm{~m}), 1494(\mathrm{~m}), 1472(\mathrm{~m}), 1448(\mathrm{~m}), 1426(\mathrm{~m}), 1369(\mathrm{~m}), 1323(\mathrm{w}), 1303(\mathrm{w}), 1267(\mathrm{w})$, $1214(\mathrm{w}), 1181(\mathrm{w}), 1095(\mathrm{~m}), 1035(\mathrm{~m}), 996(\mathrm{~m}), 814(\mathrm{~m}), 774(\mathrm{~m}), 743(\mathrm{~m}), 699(\mathrm{~s}), 661(\mathrm{w})$.

3.3.3. Synthesis of 2-(1-(2,4-Dibenzhydryl-6-fluorophenylimino)ethyl)-6-(1-(2,6-dimethylphenyl imino)ethyl)pyridylchromium(III) chloride (Cr3)

Using similar synthetic procedure and molar ratio described for the synthesis of Cr1, Cr3 was prepared by reacting 2-(1-(2,4-dibenzhydryl-6-fluorophenylimino)ethyl)-6-(1-(2,6-diisopropyl phenylimino)ethyl)pyridine $(0.15 \mathrm{~g}, 0.20 \mathrm{mmol})$ with $\mathrm{CrCl}_{3} .3 \mathrm{THF}(0.07 \mathrm{~g}, 0.20 \mathrm{mmol})$ and collected as a light green powder $(0.15 \mathrm{~g}, 83 \%)$. Anal. calcd. for $\mathrm{C}_{53} \mathrm{H}_{50} \mathrm{Cl}_{3} \mathrm{CrFN}_{3}$ (906.35): $\mathrm{H}, 5.56 ; \mathrm{C}, 70.24$; N, 4.64; Found: H, 5.67; C, 69.99; N, 4.76. FT-IR (cm $\left.{ }^{-1}\right): 3058(\mathrm{~m}), 3031(\mathrm{~m}), 2966(\mathrm{~m}), 2914(\mathrm{~m}), 1690(\mathrm{w})$, $1618\left(\mathrm{~m}, v_{\mathrm{C}=\mathrm{N}}\right), 1576(\mathrm{~m}), 1514(\mathrm{w}), 1494(\mathrm{~m}), 1471(\mathrm{~m}), 1448(\mathrm{~m}), 1426(\mathrm{w}), 1369(\mathrm{w}), 1326(\mathrm{w}), 1267(\mathrm{~m})$, $1217(\mathrm{w}), 1178(\mathrm{~m}), 1098(\mathrm{~m}), 1036(\mathrm{~m}), 996(\mathrm{~m}), 916(\mathrm{w}), 880(\mathrm{w}), 843(\mathrm{w}), 814(\mathrm{w}), 781(\mathrm{~m}), 743(\mathrm{~m})$, $699(\mathrm{~s}), 658(\mathrm{w})$.

3.3.4. Synthesis of 2-(1-(2,4-Dibenzhydryl-6-fluorophenylimino)ethyl)-6-(1-(2,6-dimethylphenyl imino)ethyl)pyridylchromium(III) chloride (Cr4)

Using similar synthetic procedure and molar ratio described for the synthesis of Cr1, Cr4 was prepared by reacting 2-(1-(2,4-dibenzhydryl-6-fluorophenylimino)ethyl)-6-(1-(mesitylimino) ethyl)pyridine $(0.14 \mathrm{~g}, 0.20 \mathrm{mmol})$ with $\mathrm{CrCl}_{3} \cdot 3 \mathrm{THF}(0.07 \mathrm{~g}, 0.20 \mathrm{mmol})$ and collected as a green powder (0.15 g, 87\%). Anal. calcd. for $\mathrm{C}_{50} \mathrm{H}_{44} \mathrm{Cl}_{3} \mathrm{CrFN}_{3}$ (864.27): $\mathrm{H}, 5.13 ; \mathrm{C}, 69.49 ; \mathrm{N}, 4.86$; Found: $\mathrm{H}, 5.17$; C, 69.41; N, 4.91. FT-IR (cm $\left.{ }^{-1}\right): 3058(\mathrm{~m}), 3024(\mathrm{~m}), 2969(\mathrm{~m}), 2917(\mathrm{~m}), 1697(\mathrm{w}), 1614\left(\mathrm{~m}, v_{\mathrm{C}=\mathrm{N}}\right)$, 1576 (s), $1492(\mathrm{~m}), 1469(\mathrm{~m}), 1448(\mathrm{~m}), 1426(\mathrm{~m}), 1373(\mathrm{~m}), 1330(\mathrm{~m}), 1270(\mathrm{~m}), 1217(\mathrm{w}), 1174(\mathrm{w})$, $1098(\mathrm{~m}), 1039(\mathrm{~m}), 996(\mathrm{~m}), 916(\mathrm{w}), 847(\mathrm{w}), 814(\mathrm{~m}), 777(\mathrm{w}), 743(\mathrm{~m}), 699(\mathrm{~s}), 661(\mathrm{w})$.

3.3.5. Synthesis of 2-(1-(2,4-Dibenzhydryl-6-fluorophenylimino)ethyl)-6-(1-(2,6-dimethylphenyl imino)ethyl)pyridylchromium(III) chloride (Cr5)

Using similar synthetic procedure and molar ratio described for the synthesis of Cr1, Cr5 was prepared by reacting 2-(1-(2,4-dibenzhydryl-6-fluorophenylimino)ethyl)-6-(1-(2,6-diethyl-4-methylphenylimino)ethyl)pyridine $(0.15 \mathrm{~g}, 0.20 \mathrm{mmol})$ with $\mathrm{CrCl}_{3} \cdot 3 \mathrm{THF}(0.07 \mathrm{~g}, 0.20 \mathrm{mmol})$ and collected as a light green powder $(0.15 \mathrm{~g}, 84 \%)$. Anal. calcd. for $\mathrm{C}_{52} \mathrm{H}_{48} \mathrm{Cl}_{3} \mathrm{CrFN}_{3}$ (892.32): H, 5.42; C, 69.99; N, 4.71; Found: H, 5.59; C, 70.01; N, 4.79. FT-IR (cm $\left.{ }^{-1}\right): 3062(\mathrm{~m}), 3024(\mathrm{~m}), 2965(\mathrm{~m}), 2917$ (m), 1690 (w), $1611\left(\mathrm{~m}, v_{\mathrm{C}=\mathrm{N}}\right), 1576(\mathrm{~s}), 1494(\mathrm{~m}), 1472(\mathrm{~m}), 1448(\mathrm{~m}), 1426(\mathrm{~m}), 1370(\mathrm{~m}), 1267(\mathrm{~m}), 1214(\mathrm{~m}), 1085(\mathrm{~m})$, $1036(\mathrm{~m}), 996(\mathrm{~m}), 848(\mathrm{w}), 810(\mathrm{~m}), 774(\mathrm{w}), 743(\mathrm{~m}), 699(\mathrm{~s}), 655(\mathrm{w})$.

\subsection{X-ray Crystallographic Studies}

Single-crystals of Cr2 and Cr4 suitable for X-ray diffraction analysis were obtained by slow diffusion of $n$-heptane into dichloromethane solution at room temperature. X-ray study was carried 
out on a MM007HF single crystal diffractometer with Confocal-monochromatized Mo-K $\alpha$ radiation (Rigaku, Tokyo, Japan) $(\lambda=0.71073 \AA$ ) at $169.99(10)$ or $170.00(15) \mathrm{K}$, and cell parameters were obtained by the global refinement of the positions of all collected reflections. The structures were solved by direct methods and refined by full-matrix least-squares on $F^{2}$. Intensities were corrected for Lorentz and polarization effects and empirical absorption. All the hydrogen atoms were placed in calculated positions. Structure solution and refinement were performed by using the SHELXT (Sheldrick, 2015, Göttingen, Germany) [76,77]. During the structural refinement, the disordered solvent was squeezed (Cr2 and Cr4) with PLATON software (Utrecht University, Utrecht, Netherlands) [78,79]. Details of the X-ray structure determinations and refinements were provided in Table 6. Electronic Supporting Information (ESI) available: CCDC 2002415 and 2002416 contain the Supporting crystallographic data for complexes $\mathrm{Cr} 2$ and $\mathrm{Cr} 4$. These data can be obtained free of charge from The Cambridge Crystallographic Data Centre via www.ccdc.cam.ac.uk/data_request/cif.

Table 6. Crystal data and structure refinement for $\mathrm{Cr} 2$ and $\mathrm{Cr} 4$.

\begin{tabular}{|c|c|c|}
\hline Complex & $\mathrm{Cr} 2$ & $\mathrm{Cr} 4$ \\
\hline CCDC No. & $2,002,415$ & $2,002,416$ \\
\hline Empirical formula & $\mathrm{C} 51 \mathrm{H} 46 \mathrm{Cl} 3 \mathrm{CrFN} 3$ & $\mathrm{C} 50 \mathrm{H} 44 \mathrm{Cl} 3 \mathrm{CrFN} 3$ \\
\hline Formula weight & 878.25 & 864.23 \\
\hline Temperature (K) & $169.99(10)$ & $170.00(15)$ \\
\hline Wavelength $(\AA)$ & 0.71073 & 0.71073 \\
\hline Crystal system & Monoclinic & Monoclinic \\
\hline Space group & $\mathrm{P} 21 / \mathrm{c}$ & $\mathrm{P} 21 / \mathrm{c}$ \\
\hline a $(\AA)$ & $15.9706(6)$ & $27.1328(5)$ \\
\hline $\mathrm{b}(\AA)$ & $39.1059(18)$ & $27.2064(4)$ \\
\hline c $(\AA)$ & $15.2664(6)$ & $17.0515(3)$ \\
\hline$\alpha\left(^{\circ}\right)$ & 90 & 90 \\
\hline$\beta\left({ }^{\circ}\right)$ & $91.412(4)$ & $104.612(2)$ \\
\hline$\gamma\left({ }^{\circ}\right)$ & 90 & 90 \\
\hline Volume $\left(\AA^{3}\right)$ & $9531.7(7)$ & $12180.1(4)$ \\
\hline Z & 4 & 4 \\
\hline Dcalcd $\left(\mathrm{g} \mathrm{cm}^{-3}\right)$ & 1.224 & 0.943 \\
\hline$\mu\left(\mathrm{mm}^{-1}\right)$ & 3.832 & 2.922 \\
\hline $\mathrm{F}(000)$ & 3656.0 & 3592.0 \\
\hline Crystal size $(\mathrm{mm})$ & $0.53 \times 0.29 \times 0.18$ & $0.20 \times 0.15 \times 0.09$ \\
\hline $2 \theta$ Range $\left({ }^{\circ}\right)$ & 4.52 to 151.222 & 4.678 to 151.134 \\
\hline Limiting indices & $-19 \leq \mathrm{h} \leq 19,-48 \leq \mathrm{k} \leq 47,-19 \leq 1 \leq 18$ & $-33 \leq \mathrm{h} \leq 25,-32 \leq \mathrm{k} \leq 34,-21 \leq 1 \leq 21$ \\
\hline No. of rflns collected & 78028 & 103413 \\
\hline No. unique rflns [R(int)] & $18,707\left[R_{\text {int }}=0.0992, R_{\text {sigma }}=0.0691\right]$ & $24,269\left[R_{\text {int }}=0.0847, R_{\text {sigma }}=0.0633\right]$ \\
\hline Completeness to $\theta(\%)$ & $100 \%$ & $100 \%$ \\
\hline Data/restraints/parameters & $18,707 / 81 / 1082$ & $24,269 / 72 / 1055$ \\
\hline The goodness of fit on $F^{2}$ & 1.349 & 1.044 \\
\hline Final $\mathrm{R}$ indices $[\mathrm{I}>2 \sigma(\mathrm{I})]$ & $\mathrm{R} 1=0.1094, \mathrm{wR} 2=0.3181$ & $\mathrm{R} 1=0.0776, \mathrm{wR} 2=0.2220$ \\
\hline $\mathrm{R}$ Indices (all data) & $\mathrm{R} 1=0.1436, \mathrm{wR} 2=0.3634$ & $\mathrm{R} 1=0.1155, \mathrm{wR} 2=0.2581$ \\
\hline
\end{tabular}

\subsection{Ethylene Polymerization Procedures}

\subsubsection{Ethylene Polymerization at 1 Atmosphere Ethylene Pressure}

The precatalyst Cr4 (1.9 mg, $2.0 \mu \mathrm{mol})$ was added to a Schlenk vessel which was equipped with a stirrer, followed by freshly distilled toluene $(30 \mathrm{~mL})$. When the chromium catalysts were completely dissolved in the toluene, the required amount of co-catalyst was then added by syringe. Under $1 \mathrm{~atm}$ of ethylene pressure, the reaction mixture kept stirring at the designated reaction temperature for 30 min. After reaction, the mixture was quenched with $10 \%$ hydrochloric acid in ethanol. The obtained polymer was washed with ethanol and dried under reduced pressure at $80^{\circ} \mathrm{C}$ and weighed. 


\subsubsection{Ethylene Polymerization at 5/10 Atmosphere Ethylene Pressure}

The high-pressure polymerization reactions were carried out in a stainless-steel autoclave $(250 \mathrm{~mL})$ equipped with a mechanical stirrer, a temperature controller and an ethylene pressure control system. Freshly distilled toluene $(25 \mathrm{~mL})$ and toluene solution with chromium complex $(50 \mathrm{~mL})$ were successively injected into the autoclave when the designated reaction temperature reached. Then the required amount of co-catalyst was injected and more toluene $(25 \mathrm{~mL})$ was introduced to complete the addition. The autoclave was immediately pressurized to the designated ethylene pressure and the stirring commenced at the same time. When the reaction time was up, stop stirring and cool the reactor. The ethylene pressure was vented and $10 \%$ hydrochloric acid in ethanol was used to quenched the reaction mixture. The obtained polymer was washed with ethanol and dried under reduced pressure at $80^{\circ} \mathrm{C}$ and weighed.

\section{Conclusions}

A series of ortho-fluorinated 2-[1-(2,4-dibenzhydryl-6-fluorophenylimino)ethyl]-6-[1-(arylimino)ethyl]pyridylchromium (III) chloride complexes has been synthesized in good yield and fully characterized including the molecular structure of complex Cr2 and Cr4 using-crystal X-ray diffraction. In the presence of MAO or MMAO, complexes Cr1-Cr5 showed exceptionally good performance toward ethylene polymerization and produced highly linear polyethylene waxes. In general, the MMAO-activated chromium catalysts displayed higher activities than that seen earlier with $\mathrm{Cr} / \mathrm{MAO}$ highlighting the effect of cocatalyst type on catalytic performance. Moreover, the activity of $\mathrm{Cr} 4 / \mathrm{MMAO}$ was especially outstanding as a result of combination effects of steric and electronic properties and reached at $20.14 \times 10^{6} \mathrm{~g}(\mathrm{PE}) \mathrm{mol}^{-1}(\mathrm{Cr}) \mathrm{h}^{-1}$ which was much higher than that of previously reported chromium analogs. This work further illustrates the systematic modification in the steric and electronic substituents of complexes providing a way to improve the catalyst performance and polymer microstructure.

Author Contributions: Design of the study and experiments, B.G. and W.-H.S.; synthesis and catalysis, B.G., Q.Z. and C.B.; manuscript, B.G., Q.Z., A.V., Y.M. and W.-H.S.; interpretation of the data obtained from the single crystal X-ray diffraction, Q.Z. and T.L. All authors have read and agreed to the published version of the manuscript.

Funding: This work was supported by the National Natural Science Foundation of China (Nos. 21871275 and 51473170).

Acknowledgments: B.G. and C.B. are thankful to CAS-TWAS President's Fellowship and A.V. thanks the Chinese Academy of Sciences President's International Fellowship Initiative (No. 2018PM0012).

Conflicts of Interest: The authors declare no conflict of interest.

\section{References}

1. Hogan, J.P. Ethylene Polymerization Catalysis over Chromium Oxide. J. Polym. Sci. Part A-1 Polym. Chem. Ed. 1970, 8, 2637-2652. [CrossRef]

2. Hogan, J.P.; Banks, R.L. Polymers and Production Thereof. U.S. Patent 2825721, 4 March 1958.

3. McDaniel, M.P. Supported Chromium Catalysts for Ethylene Polymerization. Adv. Catal. 1985, 33, 47-98.

4. Karol, F.J.; Brown, G.L.; Davison, J.M. Chromocene-Based Catalysts for Ethylene Polymerization: Kinetic Parameters. J. Polym. Sci. Polym. Chem. Ed. 1973, 11, 413-424. [CrossRef]

5. Groppo, E.; Lamberti, C.; Bordiga, S.; Spoto, A.G.; Zecchina, A. The Structure of Active Centers and the Ethylene Polymerization Mechanism on the $\mathrm{Cr} / \mathrm{SiO}_{2}$ Catalyst: A Frontier for the Characterization Methods. Chem. Rev. 2005, 105, 115-183. [CrossRef] [PubMed]

6. Karapinka, G.L. Verfahren zur Polymerisation von Athylen und Katalysator fur Dasselbe. DE1808388A1, 29 January 1970.

7. Karapinka, G.L. Polymerization of Ethylene Using Supported Bis-(cyclopentadienyl)chromium(II) Catalysts. U.S. Patent 3709853, 9 January 1973. 
8. Karol, F.J.; Karapinka, G.L.; Wu, C.; Dow, A.W.; Johnson, R.N.; Carrick, W.L. Chromocene catalysts for ethylene polymerization: Scope of the polymerization. J. Polym. Sci. Part A-1 Polym. Chem. 1972, 10, 2621-2637. [CrossRef]

9. Theopold, K.H. Homogeneous Chromium Catalysts for Olefin Polymerization. Eur. J. Inorg. Chem. 1998, 1998, 15-24. [CrossRef]

10. Theopold, K.H. Understanding chromium-based olefin polymerization catalysis. Chemtech 1997, $27,26-32$.

11. Gibson, V.C.; Spitzmesser, S.K. Advances in Non-Metallocene Olefin Polymerization Catalysis. Chem. Rev. 2003, 103, 283-315. [CrossRef]

12. Tsurugi, H.; Yamamoto, K.; Rochat, R.; Mashima, K. Non-bridged half-metallocene complexes of group 4-6 metals with chelating ligands as well-defined catalysts for $\alpha$-olefin polymerization. Polym. J. 2015, 47, 2-17. [CrossRef]

13. MacAdams, L.A.; Kim, W.-K.; Liable-Sands, L.M.; Guzei, I.A.; Rheingold, A.L.; Theopold, K.H. The $(\mathrm{Ph})_{2}$ nacnac Ligand in Organochromium Chemistry. Organometallics 2002, 21, 952-960. [CrossRef]

14. Dixon, J.T.; Green, M.J.; Hess, F.M.; Morgan, D.H. Advances in selective ethylene trimerization-A critical overview. J. Organomet. Chem. 2004, 689, 3641-3668. [CrossRef]

15. Gibson, V.C.; Redshaw, C.; Solan, G.A. Bis(imino)pyridines: Surprisingly Reactive Ligands and a Gateway to New Families of Catalysts. Chem. Rev. 2007, 107, 1745-1776. [CrossRef] [PubMed]

16. Wass, D.F. Chromium-catalysed ethene trimerisation and tetramerisation-Breaking the rules in olefin oligomerisation. Dalton Trans. 2007, 8, 816-819. [CrossRef] [PubMed]

17. McGuinness, D.S. Olefin Oligomerization via Metallacycles: Dimerization, Trimerization, Tetramerization, and Beyond. Chem. Rev. 2011, 111, 2321-2341. [CrossRef]

18. Agapie, T. Selective ethylene oligomerization: Recent advances in chromium catalysis and mechanistic investigations. Coord. Chem. Rev. 2011, 255, 861-880. [CrossRef]

19. Van Leeuwen, P.W.N.M.; Clément, N.D.; Tschan, M.J.-L. New processes for the selective production of 1-octene. Coord. Chem. Rev. 2011, 255, 1499-1517. [CrossRef]

20. Bryliakov, K.P.; Talsi, E.P. Frontiers of mechanistic studies of coordination polymerization and oligomerization of $\alpha$-olefins. Coord. Chem. Rev. 2012, 256, 2994-3007. [CrossRef]

21. Otero, A.; Fernández-Baeza, J.; Lara-Sánchez, A.; Sánchez-Barba, L.F. Metal complexes with heteroscorpionate ligands based on the bis(pyrazol-1-yl)methane moiety: Catalytic chemistry. Coord. Chem. Rev. 2013, 257, 1806-1868. [CrossRef]

22. Katla, V.; Du, S.; Redshaw, C.; Sun, W.-H. Chromium Complex Precatalysts in Ethylene Oligomerization/Polymerization. Rev. Catal. 2014, 1, 1-14.

23. Fliedel, C.; Ghisolfi, A.; Braunstein, P. ChemInform Abstract: Functional Short-Bite Ligands: Synthesis, Coordination Chemistry, and Applications of N-Functionalized Bis(diaryl/dialkylphosphino)amine-type Ligands. Chem. Rev. 2016, 116, 9237-9304. [CrossRef]

24. Alferov, K.A.; Belov, G.P.; Meng, Y. Chromium catalysts for selective ethylene oligomerization to 1-hexene and 1-octene: Recent results. Appl. Catal. A 2017, 542, 71-124. [CrossRef]

25. Bariashir, C.; Huang, C.; Solan, G.A.; Sun, W.-H. Recent advances in homogeneous chromium catalyst design for ethylene tri-, tetra-, oligo- and polymerization. Coord. Chem. Rev. 2019, 385, 208-229. [CrossRef]

26. Wass, D.F. Olefin Trimerization Using a Catalyst Comprising a Source of Chromium, Molybdenum or Tungsten and a Ligand Containing at Least One Phosphorous, Arsenic or Antimony Atom Bound to at Least One (Hetero) Hydrocarbyl Group. U.S. Patent US7141633B2, 17 January 2002.

27. Carter, A.; Cohen, S.A.; Cooley, N.A.; Murphy, A.; Scutt, J.; Wass, D.F. High activity ethylene trimerisation catalysts based on diphosphine ligands. Chem. Commun. 2002, 8, 858-859. [CrossRef] [PubMed]

28. Emrich, R.; Heinemann, O.; Jolly, P.W.; Krüger, C.; Verhovnik, G.P.J. The Role of Metallacycles in the Chromium-Catalyzed Trimerization of Ethylene. Organometallics 1997, 16, 1511-1513. [CrossRef]

29. McGuinness, D.S.; Wasserscheid, P.; Keim, W.; Morgan, D.; Dixon, J.T.; Bollmann, A.; Maumela, H.; Hess, F.; Englert, U. First Cr(III)-SNS Complexes and Their Use as Highly Efficient Catalysts for the Trimerization of Ethylene to 1-Hexene. J. Am. Chem. Soc. 2003, 125, 5272-5273. [CrossRef]

30. McGuinness, D.S.; Wasserscheid, P.; Keim, W.; Hu, C.; Englert, U.; Dixon, J.T.; Grove, C. Novel Cr-PNP complexes as catalysts for the trimerisation of ethylene. Chem. Commun. 2003, 3, 334-335. [CrossRef] 
31. Bollmann, A.; Blann, K.; Dixon, J.T.; Hess, F.M.; Killian, E.; Maumela, H.; McGuinness, D.S.; Morgan, D.H.; Neveling, A.; Otto, S.; et al. Ethylene Tetramerization: A New Route to Produce 1-Octene in Exceptionally High Selectivities. J. Am. Chem. Soc. 2004, 126, 14712-14713. [CrossRef]

32. Bochmann, M. Cationic Group 4 metallocene complexes and their role in polymerisation catalysis: The chemistry of well defined Ziegler catalysts. J. Chem. Soc. Dalton Trans. 1996, 3, 255-270. [CrossRef]

33. Kaminsky, W. Highly active metallocene catalysts for olefin polymerization. J. Chem. Soc. Dalton Trans. 1998, 9, 1413-1418. [CrossRef]

34. McKnight, A.L.; Waymouth, R.M. Group 4 ansa-Cyclopentadienyl-Amido Catalysts for Olefin Polymerization. Chem. Rev. 1998, 98, 2587-2598. [CrossRef]

35. Resconi, L.; Cavallo, L.; Fait, A.; Piemontesi, F. Selectivity in Propene Polymerization with Metallocene Catalysts. Chem. Rev. 2000, 100, 1253-1346. [CrossRef] [PubMed]

36. Coates, G.W. Precise Control of Polyolefin Stereochemistry Using Single-Site Metal Catalysts. Chem. Rev. 2000, 100, 1223-1252. [CrossRef] [PubMed]

37. Alt, H.G.; Köppl, A. Effect of the Nature of Metallocene Complexes of Group IV Metals on Their Performance in Catalytic Ethylene and Propylene Polymerization. Chem. Rev. 2000, 100, 1205-1222. [CrossRef] [PubMed]

38. McDaniel, M.P. A Review of the Phillips Supported Chromium Catalyst and Its Commercial Use for Ethylene Polymerization. Adv. Catal. 2010, 42, 123-606.

39. Esteruelas, M.A.; López, A.M.; Méndez, L.; Oliván, M.; Oñate, E. Preparation, Structure, and Ethylene Polymerization Behavior of Bis(imino)pyridyl Chromium(III) Complexes. Organometallics 2003, 22, 395-406. [CrossRef]

40. Small, B.L.; Carney, M.J.; Holman, D.M.; O’Rourke, C.E.; Halfen, J.A. New Chromium Complexes for Ethylene Oligomerization: Extended Use of Tridentate Ligands in Metal-Catalyzed Olefin Polymerization. Macromolecules 2004, 37, 4375-4386. [CrossRef]

41. Semikolenova, N.; Zakharov, V.; Echevskaja, L.; Matsko, M.; Bryliakov, K.; Talsi, E. Homogeneous catalysts for ethylene polymerization based on bis(imino)pyridine complexes of iron, cobalt, vanadium and chromium. Catal. Today 2009, 144, 334-340. [CrossRef]

42. Amolegbe, S.A.; Asma, M.; Zhang, M.; Li, G.; Sun, W.-H. Synthesis, Characterization, and Ethylene Oligomerization and Polymerization by 2-Quinoxalinyl-6-iminopyridine Chromium Chlorides. Aust. J. Chem. 2008, 61, 397-403. [CrossRef]

43. Xiao, L.; Zhang, M.; Sun, W.-H. Synthesis, characterization and ethylene oligomerization and polymerization of 2-(1H-2-benzimidazolyl)-6-(1-(arylimino)ethyl)pyridylchromium chlorides. Polyhedron 2010, 29, 142-147. [CrossRef]

44. Chen, Y.; Zuo, W.; Hao, P.; Zhang, S.; Gao, K.; Sun, W.-H. Chromium (III) complexes ligated by 2-(1-isopropyl-2-benzimidazolyl)-6-(1-(arylimino)ethyl)pyridines: Synthesis, characterization and their ethylene oligomerization and polymerization. J. Organomet. Chem. 2008, 693, 750-762. [CrossRef]

45. Zhang, Y.; Huang, C.; Hao, X.; Hu, X.; Sun, W.-H. Accessing highly linear polyethylenes by 2-(1-aryliminoethyl)-7-arylimino-6,6-dimethylcyclopenta[b]pyridylchromium(III) chlorides. RSC Adv. 2016, 6, 91401-91408. [CrossRef]

46. Huang, C.; Zhang, Y.; Solan, G.A.; Ma, Y.; Hu, X.; Sun, Y.; Sun, W.-H. Vinyl-Polyethylene Waxes with Narrow Dispersity Obtained by Using a Thermally Robust [Bis(imino)trihydroquinolyl]chromium Catalyst. Eur. J. Inorg. Chem. 2017, 36, 4158-4166. [CrossRef]

47. Huang, C.; Huang, Y.; Ma, Y.; Solan, G.A.; Sun, Y.; Hu, X.; Sun, W.-H. Cycloheptyl-fused N,N,N'-chromium catalysts with selectivity for vinyl-terminated polyethylene waxes: Thermal optimization and polymer functionalization. Dalton Trans. 2018, 47, 13487-13497. [CrossRef] [PubMed]

48. Huang, C.; Du, S.; Solan, G.A.; Sun, Y.; Sun, W.-H. From polyethylene waxes to HDPE using an $\alpha, \alpha^{\prime}$-bis(arylimino)-2,3:5,6-bis(pentamethylene)pyridyl-chromium(III) chloride pre-catalyst in ethylene polymerisation. Dalton Trans. 2017, 46, 6948-6957. [CrossRef] [PubMed]

49. Tomov, A.; Chirinos, J.J.; Jones, D.J.; Long, R.J.; Gibson, V.C. Experimental Evidence for Large Ring Metallacycle Intermediates in Polyethylene Chain Growth Using Homogeneous Chromium Catalysts. J. Am. Chem. Soc. 2005, 127, 10166-10167. [CrossRef] [PubMed]

50. Zhang, W.; Sun, W.-H.; Zhang, S.; Hou, J.; Wedeking, K.; Schultz, S.; Frölich, A.R.; Song, H. Synthesis, Characterization, and Ethylene Oligomerization and Polymerization of [2,6-Bis(2-benzimidazolyl)pyridyl]chromium Chlorides. Organometallics 2006, 25, 1961-1969. [CrossRef] 
51. Zhang, S.; Jie, S.; Shi, Q.; Sun, W.-H. Chromium(III) complexes bearing 2-imino-1,10-phenanthrolines: Synthesis, molecular structures and ethylene oligomerization and polymerization. J. Mol. Catal. A Chem. 2007, 276, 174-183. [CrossRef]

52. Zhang, M.; Wang, K.; Sun, W.-H. Chromium(III) complexes bearing 2-benzazole-1,10-phenanthrolines: Synthesis, molecular structures and ethylene oligomerization and polymerization. Dalton Trans. 2009, 32, 6354-6363. [CrossRef]

53. Gao, R.; Liang, T.; Wang, F.; Sun, W.-H. Chromium(III) complexes bearing 2-benzoxazolyl-6-aryliminopyridines: Synthesis and their ethylene reactivity. J. Organomet. Chem. 2009, 694, 3701-3707. [CrossRef]

54. Yu, J.; Liu, H.; Zhang, W.; Hao, X.; Sun, W.-H. Access to highly active and thermally stable iron procatalysts using bulky 2-[1-(2,6-dibenzhydryl-4-methylphenylimino)ethyl]-6-[1-(arylimino)ethyl]pyridine Ligands. Chem. Commun. 2011, 47, 3257-3259. [CrossRef]

55. Cao, X.; He, F.; Zhao, W.; Cai, Z.; Hao, X.; Shiono, T.; Redshaw, C.; Sun, W.-H. 2-[1-(2,6-Dibenzhydryl-4chlorophenylimino)ethyl]-6-[1-(arylimino)ethyl]pyridyliron(II) dichlorides: Synthesis, characterization and ethylene polymerization behavior. Polymer 2012, 53, 1870-1880. [CrossRef]

56. Zhang, Q.; Ma, Y.; Suo, H.; Solan, G.A.; Liang, T.; Sun, W.-H. Co-catalyst effects on the thermal stability/activity of N,N,N-Co ethylene polymerization Catalysts Bearing Fluoro-Substituted N-2,6-dibenzhydrylphenyl groups. Appl. Organomet. Chem. 2019, 33, 5134. [CrossRef]

57. Zhang, Q.; Zhang, R.; Han, M.; Yang, W.; Liang, T.; Sun, W.-H.; Tongling, L. 4,4'-Difluorobenzhydrylmodified bis(imino)-pyridyliron (II) chlorides as thermally stable precatalysts for strictly linear polyethylenes with narrow dispersities. Dalton Trans. 2020, 49, 7384-7396. [CrossRef] [PubMed]

58. Wang, S.; Li, B.; Liang, T.; Redshaw, C.; Li, Y.; Sun, W.-H. Synthesis, characterization and catalytic behavior toward ethylene of 2-[1-(4,6-dimethyl-2-benzhydryl-phenylimino)ethyl]-6-[1-(arylimino)ethyl]pyridyl metal (iron or cobalt) chlorides. Dalton Trans. 2013, 42, 9188-9197. [CrossRef]

59. Zhang, W.; Wang, S.; Du, S.; Guo, C.-Y.; Hao, X.; Sun, W.-H. 2-(1-(2,4-Bis((di(4-fluorophenyl)methyl)-6methylphenylimino)ethyl)-6-(1-(arylimino)ethyl)pyridylmetal (iron or cobalt) Complexes: Synthesis, Characterization, and Ethylene Polymerization Behavior. Macromol. Chem. Phys. 2014, 215, 1797-1809. [CrossRef]

60. Mahmood, Q.; Guo, J.; Zhang, W.; Ma, Y.; Liang, T.; Sun, W.-H. Concurrently Improving the Thermal Stability and Activity of Ferrous Precatalysts for the Production of Saturated/Unsaturated Polyethylene. Organometallics 2018, 37, 957-970. [CrossRef]

61. Mahmood, Q.; Yue, E.; Guo, J.; Zhang, W.; Ma, Y.; Hao, X.; Sun, W.-H. Nitro-functionalized bis(imino)pyridylferrous chlorides as thermo-stable precatalysts for linear polyethylenes with high molecular weights. Polymer 2018, 159, 124-137. [CrossRef]

62. Huang, C.; Vignesh, A.; Bariashir, C.; Mahmood, Q.; Ma, Y.; Sun, Y.; Sun, W.-H. Producing Highly Linear Polyethylenes by Using t-butyl-Functionalized 2,6-bis(imino)pyridylchromium (III) Chlorides. J. Polym. Sci. Part. A Polym. Chem. 2019, 57, 1049-1058. [CrossRef]

63. Huang, C.; Vignesh, A.; Bariashir, C.; Ma, Y.; Sun, Y.; Sun, W.-H. Achievement of strictly linear ultra-high molecular weight polyethylene with narrow dispersity by dint of nitro-enhanced 2,6-bis(imino)pyridylchromium chloride complexes. New J. Chem. 2019, 43, 11307-11315. [CrossRef]

64. Gansukh, B.; Zhang, Q.; Flisak, Z.; Liang, T.; Ma, Y.; Sun, W.-H. The chloro-substituent enhances performance of 2,4-bis(imino)pyridylchromium catalysts yielding highly linear polyethylene. Appl. Organomet. Chem. 2020, 34, 5471. [CrossRef]

65. Britovsek, G.J.P.; Gibson, V.C.; Hoarau, O.D.; Spitzmesser, S.K.; White, A.J.P.; Williams, D.J. Iron and Cobalt Ethylene Polymerization Catalysts: Variations on the Central Donor. Inorg. Chem. 2003, 42, 3454-3465. [CrossRef] [PubMed]

66. Sun, W.-H.; Tang, X.; Gao, T.; Wu, B.; Zhang, W.; Ma, H. Synthesis, Characterization, and Ethylene Oligomerization and Polymerization of Ferrous and Cobaltous 2-(Ethylcarboxylato)-6-iminopyridyl Complexes. Organometallics 2004, 23, 5037-5047. [CrossRef]

67. Gibson, V.C.; Redshaw, C.; Solan, G.A.; White, A.J.P.; Williams, D.J. Aluminum Alkyl-Mediated Route to Novel N,N,O-Chelates for Five-Coordinate Iron(II) Chloride Complexes: Synthesis, Structures, and Ethylene Polymerization Studies. Organometallics 2007, 26, 5119-5123. [CrossRef] 
68. Smit, T.M.; Tomov, A.K.; Britovsek, G.J.P.; Gibson, V.C.; White, A.J.P.; Williams, D.J. The effect of imine-carbon substituents in bis(imino)pyridine-based ethylene polymerisation catalysts across the transition series. Catal. Sci. Technol. 2012, 2, 643-655. [CrossRef]

69. Semikolenova, N.V.; Sun, W.-H.; Soshnikov, I.E.; Matsko, M.A.; Kolesova, O.V.; Zakharov, V.A.; Bryliakov, K.P. Origin of "Multisite-like" Ethylene Polymerization Behavior of the Single-Site Nonsymmetrical Bis(imino)pyridine Iron(II) Complex in the Presence of Modified Methylaluminoxane. ACS Catal. 2017, 7, 2868-2877. [CrossRef]

70. Gates, D.P.; Svejda, S.K.; Onate, E.; Killian, C.M.; Johnson, L.K.; White, P.S.; Brookhart, M. Synthesis of Branched Polyethylene Using ( $\alpha$-Diimine)nickel (II) Catalysts: Influence of Temperature, Ethylene Pressure, and Ligand Structure on Polymer Properties. Macromolecules 2000, 33, 2320-2334. [CrossRef]

71. Lee, L.-S.; Ou, H.-J.; Hsu, H.-L. The experiments and correlations of the solubility of ethylene in toluene solvent. Fluid Phase Equilib. 2005, 231, 221-230. [CrossRef]

72. Popeney, C.S.; Rheingold, A.L.; Guan, Z. Nickel(II) and Palladium(II) Polymerization Catalysts Bearing a Fluorinated Cyclophane Ligand: Stabilization of the Reactive Intermediate(1). Organometallics 2009, 28, 4452-4463. [CrossRef]

73. Britovsek, G.J.P.; Bruce, M.; Gibson, V.C.; Kimberley, B.S.; Maddox, P.J.; Mastroianni, S.; McTavish, S.J.; Redshaw, C.; Solan, G.A.; Strömberg, S.; et al. Iron and Cobalt Ethylene Polymerization Catalysts Bearing 2,6-Bis(Imino)Pyridyl Ligands: Synthesis, Structures, and Polymerization Studies. J. Am. Chem. Soc. 1999, 121, 8728-8740. [CrossRef]

74. Bariashir, C.; Wang, Z.; Ma, Y.; Vignesh, A.; Hao, X.; Sun, W.-H. Finely Tuned $\alpha$, $\alpha^{\prime}$-Bis(arylimino)-2,3:5,6bis(pentamethylene)pyridine-Based Practical Iron Precatalysts for Targeting Highly Linear and Narrow Dispersive Polyethylene Waxes with Vinyl Ends. Organometallics 2019, 38, 4455-4470. [CrossRef]

75. Zhang, Q.; Wu, N.; Xiang, J.; Solan, G.A.; Suo, H.; Ma, Y.; Liang, T.; Sun, W.-H. Bis-cycloheptyl-fused bis(imino)pyridine-cobalt catalysts for PE wax formation: Positive effects of fluoride substitution on catalytic performance and thermal stability. Dalton Trans. 2020, 49, 9425-9437. [CrossRef] [PubMed]

76. Sheldrick, G. SHELXT- integrated space-group and crystal-structure determination. Acta Crystallogr. Sect. A Found. Adv. 2015, A71, 3-8. [CrossRef] [PubMed]

77. Sheldrick, G.M. Crystal structure refinement with SHELXL. Acta Crystallogr. Sect. C Struct. Chem. 2015, C71, 3-8. [CrossRef] [PubMed]

78. Spek, A.L. Structure validation in chemical crystallography. Acta Crystallogr. Sect. D Biol. Crystallogr. 2009, D65, 148-155. [CrossRef] [PubMed]

79. Van Der Sluis, P.; Spek, A.L. BYPASS: An effective method for the refinement of crystal structures containing disordered solvent regions. Acta Crystallogr. Sect. A Found. Adv. 1990, A46, 194-201. [CrossRef]

Sample Availability: Samples of the compounds are available from the authors if readers make requirements.

Publisher's Note: MDPI stays neutral with regard to jurisdictional claims in published maps and institutional affiliations.

(C) 2020 by the authors. Licensee MDPI, Basel, Switzerland. This article is an open access article distributed under the terms and conditions of the Creative Commons Attribution (CC BY) license (http://creativecommons.org/licenses/by/4.0/). 